\title{
Schending van vormvereisten in het kader van een oplossingsgerichte rechtspraak: de bestuurlijke lus bekeken vanuit een rechtsvergelijkend perspectief
}

\author{
Frederic Eggermont*
}

\section{Inleiding}

De Belgische Raad van State ${ }^{\mathrm{I}}$ kan, in het kader van de beslechting van bestuurlijke geschillen, overgaan tot de vernietiging van een onwettige bestuurshandeling (en eventueel op voorhand tot de schorsing van de tenuitvoerlegging ervan). Dit is onder meer het geval wanneer de Raad van State vaststelt dat een bepaald vormvereiste niet werd nageleefd. In de Raad van State bestaat evenwel de overtuiging dat een zaak het best onmiddellijk inhoudelijk wordt afgewerkt, hoewel de vastgestelde schending van een vormvereiste al voldoende zou kunnen zijn om de vernietiging te bevelen. Dit principe werd, wat Nederland betreft, alvast met de Wet aanpassing bestuursprocesrecht van 20 december $2012,{ }^{2}$ die op I januari 2013 in werking is getreden, opgenomen in artikel 8:4Ia van de Algemene wet bestuursrecht (Awb) dat luidt als volgt: 'De bestuursrechter beslecht het hem voorgelegde geschil zoveel mogelijk definitief'.

Bepaalde vernietigingsarresten van de Raad van State, waarvan sommige hierna worden besproken, kregen veel weerklank in de media en werden zelfs bestempeld als 'absurd'. ${ }^{3}$ In het verslag van de bevoegde commissie van het Waals Parlement bij het decreet van het Waalse Gewest van 17 juli 2008 betreffende enkele vergunningen

* Prof. dr. Frederic Eggermont is deeltijds docent Rechtsmethodologie aan de rechtenfaculteit van de Vrije Universiteit Brussel en auditeur in de Raad van State. De auteur neemt een louter persoonlijk standpunt in. Dank gaat uit naar Pierrot T'Kindt, auditeur in de Raad van State, voor zijn opmerkingen op een eerste ontwerpversie van deze bijdrage, alsook naar Marc Lefever, adjunctauditeur-generaal in de Raad van State.

I Wanneer in deze bijdrage wordt gesproken over de 'Raad van State' wordt hiermee bedoeld de Belgische Raad van State. Indien het evenwel gaat over de Nederlandse of de Franse Raad van State wordt dit steeds verduidelijkt in de tekst.

$2 \quad$ Stb. 2012, 682.

3 M. Goethals, 'Raad van State legt juridische bom onder dertig provinciale uitvoeringsplannen', De Standaard II oktober 201 . 
waarvoor er dringende redenen van algemeen belang bestaan, ${ }^{4}$ waarbij een procedure sui generis werd ingevoerd na afloop waarvan de decreetgever zich de bevoegdheid voorbehield om bepaalde stedenbouwkundige vergunningen, milieuvergunningen en globale vergunningen te verlenen, werd zelfs onderstreept dat het decreet het mogelijk moest maken de sereniteit in bepaalde dossiers terug te vinden, ${ }^{5}$ omdat het oordeel van de Raad van State het algemeen belang in gevaar bracht. Het werd aldus noodzakelijk geacht 'dat op hol slaan van de procedure waarbij de Raad van State de decreten op extreme wijze interpreteert, te stoppen'. ${ }^{6}$

Lancksweerdt stelt over dergelijke kritiek aan het adres van een blijkbaar op hol geslagen Raad van State het volgende:

\begin{abstract}
'Maar kan men aan een rechtscollege verwijten dat het gewoon de wet toepast? Wie vindt dat een rechtscollege in bepaalde gevallen de wet terzijde moet schuiven - bijvoorbeeld om redenen van algemeen belang - moet dit duidelijk zo zeggen en dient goed te beseffen dat een van de basisprincipes van de rechtstaat, met name dat de overheid gebonden is aan wetgeving, dan op de helling komt te staan. Als wetgeving ongewenste consequenties heeft, ligt het probleem bij die wetgeving, niet bij diegene wiens opdracht het is ze toe te passen.?
\end{abstract}

In de ontwerpverklaring over het algemeen beleid van I december 201 I van de federale regering-Di Rupo I werd uiteindelijk het beleidsplan opgevat 'om beter aan de concrete bekommernissen te beantwoorden' en dan ook 'in het belang van de rechtzoekende en de bestuurlijke overheden' voorstellen te bekijken die de rechtspleging voor de Afdeling Bestuursrechtspraak van de Raad van State zouden verbeteren. ${ }^{8}$ In navolging van die verklaring keurde de Ministerraad in april 2013 een voorontwerp van wet houdende hervorming van de bevoegdheid, de procedureregeling en de organisatie van de Raad van State goed, ${ }^{9}$ dat echter heden nog in afwachting is van zijn neerlegging voor stemming in de Kamer van Volksvertegenwoordigers en de Senaat.

In deze bijdrage wordt onderzocht op welke manier de Belgische Raad van State, in het kader van een oplossingsgerichte rechtspraak en met zijn te verwachten nieuwe

Belgisch Staatsblad (BS) 25 juli 2008.

5 Rapport présenté au nom de la Commission de l'Aménagement du territoire, des Transports, de l'Energie et du Logement, Parl.St. W.Parl. 2007-08, nr. 805/5, p. I2.

6 Id., I6. Nederlandse vertaling, zoals weergegeven in GwH 22 november 20I2, nr. I44/20I2.

7 E. Lancksweerdt, 'Pleidooi voor een breed perspectief inzake een mogelijke hervorming van de bestuursrechtspraak', TBP 20II/7, (407) 407.

8 Ontwerpverklaring te vinden op <www.vvsg.be/SiteCollectionDocuments/2oriI2orregeerak koord.pdf $>$ (laatst geconsulteerd op 4 juli 20I3).

9 Persbericht van 26 april 2013 getiteld 'Goedkeuring van de hervorming van de Raad van State: de efficiëntie verbeteren van de administratieve justitie ten voordele van iedereen', te vinden op <www.milquet.belgium.be/sites/default/files/I30426-CP-Goedkeuring\%2ovan\%2ode\%2oher vorming\%2ovan\%2ode\%2oRaad\%2ovan\%2oState.pdf> (laatst geconsulteerd op 4 juli 20I3). Wanneer in deze bijdrage wordt gesproken over 'het voorontwerp', dan wordt hiermee dat voorontwerp, waarmee de rechtspleging voor de Raad van State wordt hervormd en o.m. de bestuurlijke lus wordt ingevoerd, bedoeld. 
verruimde bevoegdheden aan geschillenoplossing kan doen wanneer hij vaststelt dat een bestuurshandeling onwettig is wegens de schending van een vormvereiste, en of de Nederlandse techniek van de bestuurlijke lus ('boucle administrative'), ${ }^{\text {, }}$ die wordt aangewend door de Nederlandse Raad van State en heden in België als het ware als symbool staat voor de hervorming van de Raad van State, ${ }^{\text {II }}$ wel geschikt is voor laatstgenoemde.

\section{Het herstellen van de schending van vormvereisten door gebruik te maken van de bestuurlijke lus}

De Belgische Staat is een rechtsstaat, wat inhoudt dat de overheid is gebonden door het objectief recht waarvan zij toepassing moet verzekeren. Het komt toe aan de Raad van State om te waken over het wettige optreden van de overheid en over de normenhiërarchie. Wat betreft de schending van vormvereisten heeft de voorzitter van de Raad van State, Stevens, het als volgt verwoord:

'Daarnaast kijken we of de substantiële vormvereisten zijn nageleefd. Als politici vastgelegd hebben dat er een bepaald advies nodig is, dan moet dat er ook zijn. Het zijn de politici die de regels maken, wij doen dat niet. Vindt men dat zo'n advies niet echt nodig is, dan moet men dat niet verplichten'. ${ }^{12}$

Hoewel de overheid zich bepaalde regels oplegt voor het nemen van een beslissing, acht zij het blijkbaar toch nodig dat een zekere soepelheid aan de dag wordt gelegd wanneer zij haar eigen regels miskent. Ook tijdens de mondelinge behandeling in de Eerste Kamer der Staten-Generaal van het wetsvoorstel, dat uiteindelijk voormelde Wet aanpassing bestuursprocesrecht van 20 december 2012 is geworden, bleek dat twijfel rees over de vraag of hiermee geen afbreuk werd gedaan 'aan een fundamentele doelstelling van het bestuursprocesrecht dat de overheid zich aan het recht houdt'. ${ }^{3}$

Io In deze bijdrage wordt echter niet ingegaan op bemiddeling als geschillenbeslechting, zoals dit ook is opgenomen in het voorontwerp.

II R. Born, 'La réforme du Conseil d'Etat ou du compromis incertain aux probables avancées', Publicum juni 20I3, I4: 'La boucle administrative est l'autre grande mesure de cette réforme. Comme je l'ai indiqué d'emblée, elle en constitue peut-être d'ailleurs le symbole. Du côté flamand, cette boucle est quelque chose d' "onbespreekbaar" ou de non négociable: on veut de la boucle partout. Mais du côté des barreaux aussi, c'est devenu un autre symbole, celui du déséquilibre de la réforme'.

I2 Interview in De Morgen van 22 december 2012 met als titel 'Wij schorsen niet voor een komma'.

I3 Zie brief van 17 december 2012 van de Nederlandse minister van Veiligheid en Justitie aan de voorzitter van de Eerste Kamer der Staten-Generaal, te vinden op <www.eerstekamer.nl/behandeling/20I2I2I7/brief_inzake_wetsvoorstel/document3/f=/vj5k858tcdyn.pdf $>$ (laatst geconsulteerd op 4 juli 20I3). 
In het verslag van de commissie Investeringsprojecten onder het voorzitterschap van de gouverneur van de provincie Antwerpen, Berx, ${ }^{14}$ werden de volgende voorstellen gedaan:

'Voorstel 40: bied een bestuurlijke overheid waarvan een beslissing wordt aangevochten bij een bestuursrechter de mogelijkheid om procedure-en vormfouten die tot de onrechtmatigheid van een bestuurshandeling (kunnen) leiden de mogelijkheid om deze tijdig te herstellen.

Voorstel 41: Beschouw procedure- en vormfouten als irrelevant wanneer ze, na opschorting van de rechterlijke procedure daartoe, correct zijn hersteld en/of rechtgezet. Meer concreet moet een bestuurshandeling niet langer wegens onrechtmatig worden vernietigd wanneer bijvoorbeeld:

- de voor de uitvaardiging van de bestuurshandeling noodzakelijke aanvraag later naderhand werd ingediend;

- de noodzakelijke motivering naderhand werd gegeven;

- de noodzakelijke raadpleging van een belanghebbende naderhand werd gehouden;

- naderhand aan de hoorplicht werd voldaan;

- een noodzakelijk advies naderhand werd ingewonnen.

Burgers krijgen terecht steeds vaker de mogelijkheid om een onvolledig dossier te vervolledigen. Zo ook moeten bestuurlijke overheden de kans krijgen om procedure- en vormfouten tijdig te herstellen.

Uiteraard mag het achteraf herstellen van vormfouten niet als strategie worden aangewend.

Voorstel 42: Voorzie in de mogelijkheid voor elke bestuurlijke overheid om schrijffouten, rekenfouten en evidente onjuistheden steeds te corrigeren.

Voorstel 43: Verleen de mogelijkheid aan de bestuurlijke overheid om een foutieve bestuurshandeling om te zetten in een andere, wanneer ze hetzelfde doel beoogt en door de uitvaardigende overheid volgens de voorgenomen procedure en vorm wettig kon worden genomen en de voorwaarden voor haar uitvaardiging zijn vervuld.

Wanneer een bestuurlijke overheid gebruik maakt van één van deze mogelijkheden om procedureen/of vormfouten te herstellen, heeft het bij de bestuursrechter aanhangig gemaakte geschil uiteraard nog slechts betrekking op de herstelde bestuurshandeling en niet langer op de bestuurshandeling die initieel werd aangevochten.' ${ }^{15}$

In 2012 werd het systeem van de bestuurlijke lus voor het eerst ingevoerd in de Vlaamse regelgeving. Zo is er het decreet van 6 juli 2012 houdende wijziging van diverse bepalingen van de Vlaamse Codex Ruimtelijke Ordening, ${ }^{16}$ wat de Raad voor Vergunningsbetwistingen betreft, ${ }^{17}$ dat er in hoofdzaak toe strekt titel IV, hoofdstuk VIII, van de VCRO ${ }^{18}$ dat betrekking heeft op de Raad voor Vergunningsbetwistingen, integraal te vervangen. Voorts werd het jaar daarop het voorontwerp opgesteld dat de mogelijkheden om een genuanceerde uitspraak te doen voor de Raad

I4 Hierna: commissie-Berx.

I5 Uittreksel van het verslag van de commissie-Berx te vinden in Wetsvoorstel (C. Van Cauter en P. Dewael) tot wijziging van de wetten op de Raad van State, gecoördineerd op I2 januari I973, Parl.St. Kamer 20I2-I3, nr. 2583/OOI, p. I4-I5.

I6 Hierna: VCRO.

I7 BS 24 augustus 20I2; inwerkingtreding op I september 2012.

I8 BS 20 augustus 2009 en meermaals gewijzigd. 
van State uitbreidt, waarbij onder meer de bestuurlijke lus wordt ingevoerd in de procedureregeling.

Tevens kan nog worden verwezen naar artikel ${ }_{3} 8$ van het (Vlaamse) Provinciedecreet van 9 december 2005 en artikel 142 van het Gemeentedecreet van I5 juli 2005, zoals vervangen bij de decreten van 29 juni 2012, ${ }^{19}$ die betrekking hebben op de (Vlaamse) Beroepscommissie voor tuchtzaken die optreedt als beroepsinstantie voor alle tuchtbeslissingen van gemeenten, provincies en openbare centra voor maatschappelijk welzijn. Voormelde artikelen luiden als volgt:

'Binnen zestig dagen na de dag van ontvangst van het tuchtdossier spreekt de Beroepscommissie voor tuchtzaken zich uit over het beroep. De Beroepscommissie voor tuchtzaken deelt de datum waarop ze het tuchtdossier heeft ontvangen, mee aan de tuchtoverheid en de indiener van het beroep.

De Beroepscommissie voor tuchtzaken kan de oorspronkelijke termijn van zestig dagen tweemaal verlengen met een termijn van zestig dagen. Ze brengt, voor het verstrijken van de termijn van zestig dagen, de tuchtoverheid en het personeelslid op de hoogte van de verlengde termijn.

Onverminderd de termijn bedoeld in het eerste en tweede lid, kan de Beroepscommissie voor tuchtzaken de tuchtoverheid in de gelegenheid stellen om binnen een bepaalde termijn een onwettigheid in de bestreden beslissing te herstellen. In voorkomend geval deelt de Beroepscommissie voor tuchtzaken partijen mee op welke wijze het beroep verder wordt behandeld na kennisname van de beslissing van de tuchtoverheid tot herstel van de onwettigheid en uiterlijk na het verstrijken van deze termijn om de onwettigheid te herstellen.

Indien de Beroepscommissie voor tuchtzaken het beroep gegrond verklaart, vernietigt zij de bestreden beslissing. ${ }^{20}$

I9 Decreet van 29 juni 2012 tot wijziging van het Gemeentedecreet van I5 juli 2005, BS 8 augustus 20I2; inwerkingtreding op I januari 2013 zoals bepaald bij besluit van de Vlaamse Regering van 7 september 2012. Decreet van 29 juni 2012 tot wijziging van het Provinciedecreet van 9 december 2005, BS 3 augustus 20I2; inwerkingtreding op I december 2012 zoals bepaald bij besluit van de Vlaamse Regering van 7 september 2012.

20 Vóór de opheffing van art. I4I van het Gemeentedecreet bij het decreet van 29 juni 2012 voorzag dat artikel in een hervormingsrecht voor de Beroepscommissie voor tuchtzaken. Het Witboek Interne Staatshervorming (p. 72) voorziet evenwel in de afschaffing van dat hervormingsrecht 'bij de integratie van de beroepscommissie in het Vlaamse Bestuursrechtcollege' dat er echter (tot op heden) niet is gekomen (het Witboek is te vinden op <www.vvsg.be/VVSG\%20en\%20Vlaams\%20 beleid/Documents/Witboek_8april2oII.pdf>, laatst geconsulteerd op 4 juli 20I3). In S. Verbist, 'De intrekkings- en wederbeslissingsbevoegdheid van de lokale tuchtoverheid in het licht van de hervormingsbevoegdheid van de Beroepscommissie voor tuchtzaken. Toch een bestuurlijke lus in Vlaanderen?' in: D. D'Hooghe, K. Deketelaere en A.M. Draye (red.), Liber amicorum Marc Boes, Brugge: Die Keure 20II, (575) 582-583, wordt geargumenteerd dat 'de (eerste) tuchtoverheid, na te zijn overgegaan tot intrekking van een tuchtbesluit, op grond van artikel I30, $\$ 4$ Gemeentedecreet de tuchtrechtelijke vervolging kan hernemen en a fortiori een nieuwe tuchtbeslissing kan nemen. Aldus is er, voor wat betreft het tuchtrecht van lokale overheden, in Vlaanderen althans één voorbeeld voorhanden van een formele bestuurlijke lus'. Art. I30 \$ 4 van het Gemeentedecreet luidt als volgt: 'Als de tuchtstraf wordt vernietigd, kan de tuchtoverheid vanaf de datum van de kennisgeving van de vernietiging, de tuchtrechtelijke vervolging hernemen gedurende het gedeelte van de in $\S$ I bedoelde termijn dat overbleef bij het instellen van de vervolging en minstens gedurende een termijn van drie maanden.' 
De Beroepscommissie voor tuchtzaken kan dus, als orgaan van actief bestuur, ${ }^{21}$ de tuchtoverheid in de mogelijkheid stellen om een onwettigheid in de beslissing te herstellen, wat in de parlementaire voorbereidende werkzaamheden wordt omschreven als een toepassing van de bestuurlijke lus. ${ }^{22}$

\section{I Raad voor Vergunningsbetwistingen}

Procedure voor het gebruik van de bestuurlijke lus voor de Raad voor Vergunningsbetwistingen

De (Vlaamse) Raad voor Vergunningsbetwistingen doet als administratief rechtscollege, bij wijze van arresten, uitspraak over de beroepen die worden ingesteld tot vernietiging van: (I) vergunningsbeslissingen, zijnde uitdrukkelijke of stilzwijgende bestuurlijke beslissingen, genomen in laatste administratieve aanleg, betreffende het afgeven of weigeren van een vergunning, (2) valideringsbeslissingen, zijnde bestuurlijke beslissingen houdende de validering of de weigering tot validering van een as-built-attest, ${ }^{23}$ en (3) registratiebeslissingen, zijnde bestuurlijke beslissingen waarbij een constructie als 'vergund geacht' wordt opgenomen in het vergunningenregister of waarbij een dergelijke opname wordt geweigerd. ${ }^{24}$

\section{Artikel 4.8.2 lid 2 en 3 VCRO luiden als volgt:}

'De Raad vernietigt de bestreden vergunnings-, validerings- of registratiebeslissing wanneer die beslissing onregelmatig is. Een beslissing is onregelmatig wanneer zij in strijd is met regelgeving, stedenbouwkundige voorschriften of beginselen van behoorlijk bestuur.

Als de Raad een beslissing vernietigt, kan hij het bestuur dat de vernietigde beslissing nam, bevelen om een nieuwe beslissing te nemen binnen de termijn die hij bepaalt. De Raad kan daarbij:

$1^{\circ}$ welbepaalde onregelmatige motieven of kennelijk onredelijke motieven aanwijzen die bij de totstandkoming van de nieuwe beslissing niet kunnen worden betrokken;

2I Indien evenwel de Beroepscommissie voor tuchtzaken zou worden opgenomen in het eventueel op te richten Vlaams Bestuursrechtcollege, dan zou zij worden opgenomen in een rechtsprekend orgaan met volle rechtsmacht.

22 Amendement nr. 70 (L. Dehandschutter e.a.) op het ontwerp van decreet tot wijziging van het Gemeentedecreet van I5 juli 2005, Parl.St. Vl.Parl. 20II-I2, nr. I467/IO: 'Het hervormingsrecht van de Beroepscommissie voor tuchtzaken, als orgaan van actief bestuur, wordt met betrekking tot de straftoemeting niet langer als wenselijk beschouwd en wordt daarom afgeschaft. In de nieuwe regeling behoudt de beroepscommissie haar vernietigingsbevoegdheid en kan ze in het kader van de problematiek van de bestuurlijke lus, bij tussenbeslissing, de tuchtoverheid in de gelegenheid stellen om onwettigheden te herstellen. In de tussenbeslissing waarbij de termijn om uitspraak te doen wordt verlengd, kan beslist worden dat de tuchtoverheid binnen een termijn een onwettigheid kan herstellen.' Zie ook amendement nr. 7I op voormeld ontwerp van decreet, alsook amendement nr. 34 (L. Dehandschutter e.a.) op het ontwerp van decreet tot wijziging van het Provinciedecreet 9 december 2005, Parl.St. Vl.Parl. 20II-I2, nr. I493/4.

23 Een as-builtattest is een attest waarin wordt verklaard dat handelingen betreffende een constructie of een gebouwencomplex niet of slechts marginaal afwijken van de plannen die het voorwerp uitmaken van de stedenbouwkundige vergunning of de melding (art. 99, eerste lid, decreet 27 maart 2009 tot aanpassing en aanvulling van het ruimtelijk plannings-, vergunningen- en handhavingsbeleid, BS 15 mei 2009).

Art. 4.8.2 lid I VCRO. 
$2^{\circ} \quad$ specifieke rechtsregelen of rechtsbeginselen aanwijzen die bij de totstandkoming van de nieuwe beslissing moeten worden betrokken;

$3^{\circ}$ de procedurele handelingen omschrijuen die voorafgaand aan de nieuwe beslissing moeten worden gesteld'.

De Raad voor Vergunningsbetwistingen kan dus meer dan zomaar vernietigen, want hij kan het bestuur bevelen om een nieuwe beslissing te nemen waarbij hij specifieke instructies kan geven. Toch drongen aanpassingen aan de procedure voor de Raad voor Vergunningsbetwistingen zich op, omdat 'niet [kan] worden ontkend dat de bij de Raad ingediende beroepen niet steeds binnen een redelijke termijn worden berecht. ${ }^{25}$ Daarbij werd, wat betreft de bevoegdheid, ervoor geopteerd om de uitspraakmogelijkheden van de Raad voor Vergunningsbetwistingen te verruimen door de introductie van onder meer de bestuurlijke lus. ${ }^{26}$ Deze verruiming wordt in de parlementaire stukken als volgt verantwoord:

'Thans heeft de Raad enkel een vernietigingsbevoegdheid. Stelt de Raad vast dat een bij hem aangevochten beslissing door een onwettigheid is aangetast, dan moet hij de vernietiging uitspreken. Of het nu gaat om de schending van een herstelbaar procedure- of vormgebrek die de inhoud van de beslissing niet heeft beïnvloed dan wel een materiële onwettigheid, de Raad heeft geen andere keuze dan de beslissing te vernietigen.

Zowel voor het bestuur als voor de rechtzoekende is dat een onbevredigende situatie. Door de vernietiging van de bestreden vergunningsbeslissing op grond van één middel is het geschil niet noodzakelijk opgelost, zeker niet als de vernietiging is uitgesproken op grond van de schending van een vormvoorschrift. De beslissing kan nog door andere onwettigheden zijn aangetast waarover de Raad zich niet heeft uitgesproken. Het vergunningverlenende bestuursorgaan dat zijn beslissing vernietigd ziet, moet bij het hernemen van de beslissing het gezag van het arrest eerbiedigen en minstens de door de Raad vastgestelde onwettigheid herstellen. Andere onwettigheden die bij de berechting van het vernietigingsberoep niet werden onderzocht, kunnen dus opnieuw worden begaan, zonder dat daar overigens kwade trouw mee hoeft gemoeid te zijn. Niet zelden is het zelfs niet zeker of de onwettigheid die tot de vernietiging heeft geleid, wel afdoende is hersteld. De verzoeker die de vernietiging heeft verkregen, zal dus opnieuw beroep moeten instellen bij de Raad als hij zich niet neerlegt bij de nieuwe beslissing. Een carrousel van beroepen en vernietigingen kan zo op gang worden gebracht om na jaren van procederen te weten of de beslissing door de beugel kan of niet. Voor alle betrokkenen betekent dat procedureleed, kosten en tijdverlies.

Om een bij hem gebracht geschil definitief te kunnen oplossen, moet de Raad over een ruimere waaier van uitspraakbevoegdheden beschikken dan enkel de vernietiging. Een aanzet voor een actievere en oplossingsgerichte rol van de Raad is al te vinden in artikel 4.8 .3 , 1 , tweede lid, van

25 Parl.St. Vl.Parl. 20II-I2, nr. I509/I, p. 2. In het jaarverslag 20II van de Vlaamse Ombudsdienst (Parl.St. Vl.Parl. 20II-I2, nr. 4I/I) wordt gesproken over een 'echt wel geheel onaanvaardbare achterstand', waarvoor zowel de Raad zelf als de Vlaamse beleidsmakers een erg grote verantwoordelijkheid dragen (p. 50-5I). Er moet evenwel worden opgemerkt dat de Raad voor Vergunningsbetwistingen niet beschikt over de middelen waarover de Raad van State beschikt (zo is er geen auditoraat in de Raad voor Vergunningsbetwistingen).

26 De nieuwe procedure geldt voor de verzoekschriften ingediend vanaf I september 20I2. Voor de verzoekschriften ingediend tot en met $3 \mathrm{I}$ augustus 2012 wordt de voormalige regelgeving toegepast. 
de VCRO, dat het rechtscollege de bevoegdheid verleent de vernietiging vergezeld te doen gaan van de instructie aan het vergunningverlenende bestuursorgaan om een nieuwe beslissing binnen een bepaalde termijn te nemen en daarbij onregelmatige of kennelijk onredelijke motieven aan te wijzen die niet bij de voorbereiding van de nieuwe beslissing mogen worden betrokken, rechtsregels of -beginselen aan te wijzen die bij de voorbereiding van de nieuwe beslissing moeten worden betrokken of de procedurele handelingen te omschrijuen die moeten worden gesteld alvorens de nieuwe beslissing kan worden genomen.

Dit voorstel gaat verder en wil de Raad de bevoegdheid verlenen om via een tussenarrest het vergunninguerlenende bestuursorgaan in staat te stellen om nog tijdens de procedure bij de Raad zelf de onrechtmatigheden in de beslissing te herstellen of te laten herstellen. Dit procedé, dat in het Nederlandse bestuursrecht bekendstaat als de "bestuurlijke lus", is erop gericht een geschil, zonder dat het tot een vernietiging komt, definitiefte beslechten als de bestreden beslissing enkel blijkt te zijn aangetast door onwettigheden die kunnen worden hersteld. Het herstel kan bestaan in een gecorrigeerde beslissing of het indienen van een extra schriftelijk stuk. Om enkele voorbeelden te geven: de Raad kan het bestuur uitnodigen de formele motivering van de beslissing aan te vullen, een onbeantwoord gebleven bezwaarschrift te weerleggen, een ten onrechte niet gevraagd advies alsnog in te winnen of een al uitgebracht advies bij de beoordeling te betrekken.

Een zinvolle toepassing van de bestuurlijke lus houdt in principe in dat de Raad alle middelen onderzoekt. Het heeft duidelijk geen enkele zin dat de Raad beveelt dat de bestuurlijke lus wordt gevolgd om vervolgens - nadat het vergunninguerlenende bestuursorgaan de onwettigheid heeft hersteld - vast te stellen dat de beslissing moet worden vernietigd op grond van een onwettigheid die niet te remediëren valt. Minstens moet de vernietiging steunen op een middel dat is ontleend aan een onherstelbare onwettigheid, waardoor het ruimste rechtsherstel wordt geboden.

De invoering van de bestuurlijke lus zal uiteraard geen alleenzaligmakende oplossing zijn. Niet alle onwettigheden kunnen worden hersteld. Het is evident dat ook veel zal afhangen van een oordeelkundige toepassing door de Raad en het vergunningverlenende bestuursorgaan. Niettemin mag worden verwacht dat de regeling zal leiden tot meer uitspraken die het geschil definitief beslechten, met andere woorden dat er minder vernietigingen worden uitgesproken die het geschil niet volledig oplossen en nieuwe beroepen tot vernietiging uitlokken. Iedereen heeft daar baat bij. De burger weet dat de vergunningsbeslissing enkel door herstelbare onwettigheden is aangetast en blijft op die manier bespaard van wat in de rechtsliteratuur een "pyrrusoverwinning" wordt genoemd, dat wil zeggen een vernietiging die op termijn niets oplevert. Als de beslissing integendeel door onherstelbare inhoudelijke onwettigheden is aangetast, krijgt de overheid dat meteen te horen en weet ze dus dat ze niet opnieuw dezelfde beslissing kan nemen.

Met de invoering van de bestuurlijke lus wordt tegemoetgekomen aan een van de aanbevelingen in het verslag van de Commissie Investeringsprojecten - de "commissie-Berx" - "Naar een snellere en betere besluitvorming over complexe projecten". Daarin wordt onder meer voorgesteld om, door een verruiming en verfijning van de uitspraakbevoegdheden, de Raad voor Vergunningsbetwistingen de rol van een actieve(re) bestuursrechter aan te meten. ${ }^{27}$ 
Het door het decreet van 6 juli 2012 vervangen artikel 4.8.4 VCRO luidt nu als volgt:

'\$1. Ter oplossing van een voor de Raad gebrachte betwisting kan de Raad het vergunninguerlenende bestuursorgaan in elke stand van het geding met een tussenuitspraak de mogelijkheid bieden om binnen de termijn die de Raad bepaalt een onregelmatigheid in de bestreden beslissing te herstellen of te laten herstellen, tenzij belanghebbenden, vermeld in artikel 4.8.11, daardoor onevenredig kunnen worden benadeeld.

Onder de onregelmatigheid in de bestreden beslissing, vermeld in het eerste lid, wordt verstaan een onregelmatigheid die herstelbaar is zodat de bestreden beslissing niet langer onregelmatig is in de zin van artikel 4.8.2, tweede lid, en de beslissing gehandhaafd kan blijuen.

$\S 2$. Het vergunninguerlenende bestuursorgaan deelt de Raad binnen een door de Raad bepaalde termijn mee of het gebruikmaakt van de mogelijkheid om een onregelmatigheid in de bestreden beslissing te herstellen of te laten herstellen.

Als het vergunninguerlenende bestuursorgaan overgaat tot herstel van de onregelmatigheid, deelt het de Raad schriftelijk en binnen de hersteltermijn, vermeld in paragraaf 1 , mee op welke wijze de onregelmatigheid is hersteld.

Partijen kunnen binnen de door de Vlaamse Regering bepaalde vervaltermijnen schriftelijk hun zienswijze meedelen over de wijze waarop de onregelmatigheid is hersteld.

$\S 3$. De Raad deelt de partijen mee op welke wijze het beroep verder wordt behandeld na :

$1^{\circ}$ ontvangst van de mededeling van het vergunningverlenende bestuursorgaan dat deze geen gebruikmaakt van de hem geboden mogelijkheid, overeenkomstig paragraaf 2, eerste lid;

$2^{\circ}$ het ongebruikt verstrijken van de door de Raad bepaalde termijn, vermeld in paragraaf 2 , eerste lid;

$3^{\circ}$ het ongebruikt verstrijken van de termijn, vermeld in paragraaf 2, tweede lid; of

$4^{\circ}$ ontvangst van de zienswijzen, overeenkomstig paragraaf 2 , derde lid.

$\S 4$. De proceduretermijnen worden geschorst vanaf de datum van het tussenarrest, vermeld in paragraaf 1 , eerste lid, tot de datum van mededeling, vermeld in paragraaf 3.

$\S 5$. Na het advies van de Raad te hebben gevraagd, kan de Vlaamse Regering aanvullende maatregelen bepalen die voor de uitvoering van deze onderafdeling nodig zijn.'

In de toelichting bij het voorstel, dat uiteindelijk voormeld decreet van 6 juli 2012 is geworden, wordt erop gewezen dat 'een zinvolle toepassing' van de bestuurlijke lus in principe inhoudt dat de Raad voor Vergunningsbetwistingen alle middelen onderzoekt. ${ }^{28}$ De bestuurlijke lus toepassen, waarna de Raad toch overgaat tot vernietiging wegens een niet te remediëren onwettigheid, zou namelijk het doel van de bestuurlijke lus negeren. Dit uitgangspunt kan evenwel leiden tot een verdere belasting van de Raad voor Vergunningsbetwistingen, ook omdat een 'tegensprekelijk vooronderzoek' moet worden gevoerd aangaande de herstelbaarheid van het gebrek. ${ }^{29}$ In de toelichting bij het voorstel van decreet wordt alvast verduidelijkt dat in de volgende situatie geen gebruik mag worden gemaakt van de bestuurlijke lus:

28 Parl.St. Vl.Parl. 20II-I2, nr. I509/I, p. 4.

29 Parl.St. Vl.Parl. 20II-I2, nr. I509/I, p. 9. 


\begin{abstract}
'De bestuurlijke lus mag niet worden toegepast indien belanghebbenden die beroep bij de Raad hadden kunnen instellen of ingesteld hebben daardoor onevenredig kunnen worden benadeeld. Als fouten in de bestreden beslissing tijdens de vernietigingsprocedure worden hersteld waardoor de bestreden beslissing verandert, is dat voor deze belanghebbenden niet zichtbaar, terwijl zij daardoor wel ernstig zouden kunnen worden benadeeld.

De vraag is wanneer de Raad het mogelijk onevenredig nadeel voor deze belanghebbenden aanwezig acht. Een ruime interpretatie kan ertoe leiden dat de Raad weinig gebruikmaakt van de bestuurlijke lus, waardoor tijdswinsten verloren kunnen gaan. Aan de andere kant kan een enge interpretatie op gespannen voet staan met de rechtsbescherming van belanghebbenden. Het antwoord moet worden overgelaten aan de rechtspraak van de Raad. ${ }^{30}$
\end{abstract}

Vooraleer over te gaan tot het gebruik van de bestuurlijke lus zal de Raad voor Vergunningsbetwistingen dus niet alleen alle middelen moeten hebben onderzocht, maar ook hebben geoordeeld dat er geen belanghebbenden zijn die beroep bij de Raad hadden kunnen instellen of hebben ingesteld en door het gebruik van die bestuurlijke lus onevenredig kunnen worden benadeeld. ${ }^{3}$ Het gegeven dat de decreetgever niet wilde/kon overgaan tot een duidelijke afbakening van dit onevenredig nadeel, en de ontwikkeling van dit begrip volledig overliet aan de Raad voor Vergunningsbetwistingen, laat alvast vermoeden dat de Raad zeer behoedzaam zal omspringen met het gebruik van de bestuurlijke lus, ${ }^{32}$ wat alvast wordt aangetoond door de praktijk (of beter: het gebrek hieraan), ${ }^{33}$ waarbij evenwel onmiddellijk moet worden opgemerkt dat er waarschijnlijk heden nog maar weinig zaken kunnen worden behandeld op basis van de nieuwe procedure en de mogelijkheid om de bestuurlijke lus aan te wenden zich dus nog maar zelden heeft voorgedaan.

De vraag rijst evenwel of het vereiste dat er geen belanghebbenden zijn die beroep bij de Raad hadden kunnen instellen of hebben ingesteld en door het gebruik van die bestuurlijke lus onevenredig kunnen worden benadeeld wel compatibel is met het gegeven dat de bestreden beslissing niet mag veranderen. In de voorbereidende werkzaamheden wordt in deze context gesproken over een herstelprocedure waarna de bestreden beslissing 'verandert' waardoor voornoemd vereiste in het leven werd

30 Parl.St. Vl.Parl. 20II-I2, nr. I509/I, p. Io.

3I Zie tevens Adv.RvS 5I.I3O/I/AV van 22 mei 2012 bij het decreet van 6 juli 2012 houdende wijziging van diverse bepalingen van de VCRO, wat de Raad voor Vergunningsbetwistingen betreft, is geworden: 'Vastgesteld moet worden dat de nieuwe mogelijkheid tot uitspraak die aan de Raad wordt toegekend in het voorstel slechts summier wordt geregeld. Zo is het bijvoorbeeld niet duidelijk wat het toepassingsgebied ervan is in materieel en temporeel opzicht (aard van de herstelbare onregelmatigheden, maximale duur van de procedure), het verloop en de mogelijke gevolgen van de toepassing zelf (procedure, al dan niet mogelijkheid van een nieuwe bestuurlijke beslissing), en de waarborgen voor de rechten, alsook de eventuele betrokkenheid, van derden-belanghebbenden.' (Parl.St. Vl.Parl. 20II-I2, nr. I509/2, p. 7).

32 Het geciteerde art. 4.8.4 § I VCRO bepaalt dat de Raad voor Vergunningsbetwistingen 'kan' overgaan tot de bestuurlijke lus, zonder dat er enige verplichting is. In het verslag aan de Regering bij het besluit van de Vlaamse Regering van 13 juli 2012 houdende de rechtspleging voor de Raad voor Vergunningsbetwistingen wordt gesteld: 'Het initiatief ligt in handen van de Raad.'

33 Voor een kritiek op het feit dat, zelfs met de recentste maatregelen, de Raad voor Vergunningsbetwistingen zijn achterstand niet krijgt weggewerkt, zie X., 'Unizo wil één Vlaams rechtscollege', De Juristenkrant Io april 2013, I4. 
geroepen, maar in het uiteindelijke decreet is een herstelbeslissing met een andere inhoud niet toegelaten. Het is dan ook te betwijfelen of het vereiste nog een plaats heeft in het decreet.

In het besluit van de Vlaamse Regering van I3 juli 2012 houdende de rechtspleging voor de Raad voor Vergunningsbetwistingen ${ }^{34}$ wordt de te volgen procedure voor de toepassing van de bestuurlijke lus bepaald:

'Art. 38. De Raad vermeldt in zijn tussenuitspraak op welke wijze en binnen welke termijn de onregelmatigheid kan worden hersteld.

Art. 39. De griffier deelt binnen een ordetermijn van vijftien dagen na de dagtekening van de tussenuitspraak, vermeld in artikel 4.8.4, § 1, eerste lid, van de Vlaamse Codex Ruimtelijke Ordening van 15 mei 2009, die tussenuitspraak mee aan de partijen.

De griffier brengt de partijen ervan op de hoogte of het vergunningverlenende bestuursorgaan wil gebruikmaken van de mogelijkheid om een onregelmatigheid in de bestreden beslissing te herstellen of te laten herstellen.

Als het vergunningverlenende bestuursorgaan overgaat tot herstel van de onregelmatigheid, bezorgt de griffier een afschrift van de mededeling, vermeld in artikel 4.8.4, § 2, tweede lid, van de Vlaamse Codex Ruimtelijke Ordening van 15 mei 2009, per beveiligde zending aan de andere partijen.

Partijen kunnen binnen een vervaltermijn van dertig dagen, die ingaat de dag na de dag van de betekening, vermeld in derde lid, schriftelijk hun zienswijze meedelen over de wijze waarop de onregelmatigheid is hersteld.

Ter uitvoering van artikel 4.8.4, $\S 3$, van de voormelde codex beschikt de Raad over een ordetermijn van twintig dagen om de partijen mee te delen op welke wijze het beroep verder wordt behandeld.'35

Als voorbeeld van een geval waarin de bestuurlijke lus had kunnen worden toegepast, in plaats van een naakte vernietiging, wordt in de toelichting bij het voorstel, dat uiteindelijk het decreet van 6 juli 2012 is geworden, verwezen naar het arrest nr. 2I2.825 van 28 april 20 II van de Raad van State, waarbij de stedenbouwkundige vergunning voor de aanleg van de tramlijn Deurne-Wijnegem werd vernietigd. $3^{6}$ De bedenking kan worden gemaakt of dit nu wel een goed gekozen voorbeeld is, omdat de ontheffing van de verplichting tot het opstellen van een milieueffectrapport werd

34 BS I3 juli 2012.

35 Voor een kritiek op de inhoud van art. 38 van het besluit van de Vlaamse Regering, zie H. Bortels, 'De bestuurlijke lus: aanzet naar een meer oplossingsgerichte bestuursrechter?', ТВР 2013/5, (302) 313: 'De vraag kan worden gesteld of de Vlaamse Regering met deze bepaling haar algemene uitvoeringsbevoegdheid niet heeft overschreden. Zoals hierboven vermeld (...), is de grens tussen de uitoefening van de rechterlijke macht en de uitvoerende macht bij het geven van dergelijke aanwijzingen flinterdun. Die verplichting om aanwijzingen te geven heeft in de Nederlandse Tweede Kamer dan ook aanleiding gegeven tot uitvoerige debatten. Het is betwistbaar dat dergelijke verplichting in de Vlaamse regelgeving werd ingevoerd door de Vlaamse Regering, en aldus werd onttrokken aan enig parlementair debat.'

36 Parl.St. Vl.Parl. 20II-I2, nr. I509/I, p. 9. Zie ook wetsvoorstel (P. Van Rompuy e.a.) tot wijziging van de gecoördineerde wetten van I2 januari 1973 op de Raad van State, Parl.St. Senaat 20II-I2, nr. $1579 / \mathrm{I}$. 
vernietigd en de toepassing van die verplichting tot rapportage veel tijd in beslag zal nemen en die gegevens dienen te worden opgenomen in nieuwe besluitvorming door de overheid. Bovendien wordt in casu de bestuurlijke lus voorgesteld als remedie voor het probleem van de lange duur van de procedure dat deze zaak kenmerkte. Het beroep werd ingesteld op I2 juli 2007, waarna bij arrest nr. I83.799 van 4 juni 2008 de vordering tot schorsing werd verworpen, gevolgd door een zitting over de grond van de zaak die werd gehouden op ro december 20 io en een arrest ten gronde dat werd uitgesproken op 28 april 20II. Het probleem was gewoonweg dat er drie jaar en tien maanden zat tussen het verzoekschrift en het arrest ten gronde, terwijl de bestuurlijke lus nu net niet van aard is om de afwikkeling te bespoedigen van de rechtspleging waarin het wordt toegepast.

Tot op heden heeft de Raad voor Vergunningsbetwistingen nog geen arresten gewezen waarin toepassing werd gemaakt van de bestuurlijke lus. ${ }^{37}$ In het schorsingsarrest nr. S/2013/0045 van I9 maart 2013 heeft de Raad voor Vergunningsbetwistingen op het verzoek - weliswaar in uiterst subsidiaire orde - van de tussenkomende partij (een bouwonderneming) om toepassing te maken van artikel 4.8.4 VCRO en 'de verwerende partij de mogelijkheid te bieden om de onregelmatigheden in de bestreden beslissing te herstellen', geoordeeld dat, gegeven 'de concrete omstandigheden van het dossier, de in (...) het arrest gedane vaststellingen en het feit dat verwerende partij geen nota betreffende de vordering tot schorsing heeft neergelegd, noch aanwezig dan wel vertegenwoordigd was op de openbare zitting', de toepassing van artikel 4.8.4 VCRO 'in de huidige stand van het geding niet wenselijk' was. Het lijkt evenwel niet dat uit dit arrest kan worden afgeleid dat de Raad voor Vergunningsbetwistingen daadwerkelijk van plan is om de bestuurlijke lus te gebruiken in schorsingsprocedures; het kan ook een alleenstaand geval zijn.

Beroep tot nietiguerklaring ingesteld bij het Grondwettelijk Hof

Bij verzoekschriften van 22 en 25 februari 2013 zijn bij het Grondwettelijk Hof beroepen tot vernietiging ingesteld van de artikelen 4.8 .4 en 4.8.28 \$ 2 VCRO, zoals vervangen door artikel 5 van voornoemd decreet van 6 juli 20I2, door onder meer de Antwerpse verenigingen zonder winstoogmerk Straatego en Ademloos wegens onder andere de schending van het Verdrag van Aarhus,,$^{38}$ van Richtlijn 20II/92/EU van het Europees Parlement en de Raad van 13 december 20 I betreffende de milieueffectbeoordeling van bepaalde openbare en particuliere projecten, ${ }^{39}$ van de beginselen

37 In P.-J. Defoort en L. du Gardein, 'Wanneer vormt een voorwaarde bij een stedenbouwkundige vergunning een essentiële wijziging van de aanvraag', TROS 20I2, afl. 66, (53) 68, wordt opgeroepen dat de Raad van Vergunningsbetwistingen (in tegenstelling tot de Raad van State) zich meer 'zal inpassen in de maatschappelijke vraag en de beleidsmatige tendens naar een oplossingsgerichte overheid en rechtspraak'.

38 Zie wet van 17 december 2002 houdende instemming met het Verdrag betreffende toegang tot informatie, inspraak bij besluitvorming en toegang tot de rechter inzake milieuaangelegenheden, en met de Bijlagen I en II, gedaan te Aarhus op 25 juni I998, BS 24 april 2003.

PbEU 20I2, L 26/I. 
van het recht van verdediging, tegenspraak, onafhankelijkheid en onpartijdigheid van de rechter, de wapengelijkheid en de formele motiveringsplicht. ${ }^{40}$

De algemene vergadering van de Afdeling Wetgeving heeft in het advies bij het voorstel, dat uiteindelijk het decreet van 6 juli 2012 is geworden, alvast niet opgemerkt dat een schending van het Verdrag van Aarhus noch van Richtlijn 2011/92/EU zou voorliggen.

Toch roepen de verzoekers onder meer in dat artikel 6 lid 2 van het Verdrag van Aarhus bepaalt dat het betrokken publiek, bij openbare bekendmaking of, indien van toepassing, individueel, vroegtijdig in een milieubesluitvormingsprocedure, en op adequate, tijdige en doeltreffende wijze, wordt geïnformeerd, en dat artikel 6 lid 3 erin voorziet dat de inspraakprocedures redelijke termijnen omvatten voor de verschillende fasen, die voldoende tijd laten voor het informeren van het publiek in overeenstemming met het voorgaande lid 2 en voor het publiek om zich gedurende de milieubesluitvorming doeltreffend voor te bereiden en deel te nemen. Voorts stelt artikel 6 lid 4 dat elke partij bij het Verdrag van Aarhus voorziet in vroegtijdige inspraak, wanneer alle opties open zijn en doeltreffende inspraak kan plaatsvinden. Artikel 3 lid I van het Verdrag van Aarhus stelt dan weer dat elke partij bij dat Verdrag de noodzakelijke wet- en maatregelen neemt, met inbegrip van maatregelen om regelgevende en andere verenigbaarheid te bewerkstelligen tussen de bepalingen ter uitvoering van de bepalingen in dit Verdrag betreffende informatie, inspraak en toegang tot de rechter, alsmede passende handhavingsmaatregelen voor het instellen en in stand houden van een duidelijk, transparant en samenhangend kader voor het uitvoeren van de bepalingen van dit Verdrag.

Artikel 9 lid 2 van het Verdrag van Aarhus verplicht België, binnen het kader van zijn nationale wetgeving, om de burger toegang te verlenen tot een herzieningsprocedure voor een rechterlijke instantie en/of een ander bij wet ingesteld onafhankelijk en onpartijdig orgaan, om de materiële en formele rechtmatigheid te bestrijden van een milieurechtelijke beslissing. De procedures bij de rechter moeten, volgens artikel 9 lid 4, voorzien in passende en doeltreffende middelen, met inbegrip van, zo nodig, een dwangmiddel tot rechtsherstel en zijn billijk, snel en niet onevenredig kostbaar.

Gelet op de voorgaande bepalingen van het Verdrag van Aarhus betwisten verzoekers dan ook dat de Raad voor Vergunningsbetwistingen, die zich moet uitspreken over de wettigheid van een beslissing met een milieurechtelijke impact, andere dan milieudoelstellingen (meer bepaald opportuniteitsoverwegingen) kan aanhalen om zelfs bij de vaststelling van een onwettigheid toch niet over te gaan tot vernietiging, maar om de bestuurlijke lus te gebruiken. Tevens achten zij het niet in overeenstemming met artikel 9 van het Verdrag van Aarhus dat een eventuele herstelbeslissing

40 De zaken zijn ingeschreven onder de nummers 559I en 5597 van de rol van het Hof en werden samengevoegd. 
(dus een nieuwe beslissing) niet wordt bekendgemaakt en dat enkel de partijen in het geding hiervan kennis zouden krijgen. Derden die geen partij waren in de procedure voor de Raad voor Vergunningsbetwistingen kunnen namelijk worden benadeeld door een nieuwe handhavende beslissing. Zij hebben zich bijvoorbeeld niet $a b$ initio partij gesteld na lezing van de oorspronkelijke formele motivering van de eerste gehandhaafde beslissing, maar er kan niet worden uitgesloten dat de nieuwe formele motivering van de handhavende beslissing (waarin onder meer nieuwe elementen kunnen voorkomen) de belanghebbenden wel overtuigt om beroep in te dienen.

Voorts werpen de verzoekers op dat de bestuurlijke lus haaks staat op de onafhankelijkheid en onpartijdigheid van de rechter. Zo zou een rechter die zelf ambtshalve de bestuurlijke lus aanbiedt aan het vergunningverlenende bestuursorgaan, door zonder tegenspraak (dus in de hypothese dat de bestuurlijke lus wordt voorgesteld zonder zitting) een onregelmatigheid als herstelbaar aan te merken en dus ook te hebben geoordeeld dat belanghebbenden door de toepassing van de bestuurlijke lus niet kunnen worden benadeeld, vooringenomen zijn (of minstens de schijn tegen hebben) ten aanzien van latere opmerkingen die door de verzoeker in het geding kunnen worden gemaakt. Hoewel eventueel een wijziging in de zetelsamenstelling dit euvel zou kunnen verhelpen, wijst niets in het decreet van 6 juli 2012 noch in het besluit van I3 juli 2012 erop dat een andere bestuursrechter de zaak zou overnemen. Dat een nieuwe bestuursrechter de zaak zou moeten overnemen, past volgens de verzoekers niet in de ratio legis van de bestuurlijke lus.

Hierna zal alvast worden geargumenteerd dat de bestuurlijke lus inderdaad op gespannen voet kan komen te staan met het Verdrag van Aarhus en artikel 6 lid I van het Europees Verdrag voor de Rechten van de Mens en de Fundamentele Vrijheden. ${ }^{4}$

\subsection{Raad van State}

Al sinds 2oro hebben de korpschefs van de Raad van State te kennen gegeven dat zij van oordeel zijn dat de Raad van State over andere instrumenten dient te beschikken dan de loutere vernietiging annex schorsing. Ook het Vlaams Parlement had in een resolutie laten weten te wensen dat de Raad van State de bestuurlijke lus zou kunnen aanwenden. ${ }^{42}$ Aan deze verzuchting werd uiteindelijk tegemoetgekomen in 2013 toen een voorontwerp met dit doel werd opgesteld. De hierna volgende bespreking van de voorgestelde wijzigingen gaat er uiteraard van uit dat het voorontwerp uiteindelijk wordt aangenomen en in de vorm zoals het werd opgesteld in april 20I3. Tevens bepaalt het voorontwerp dat de Koning nog een besluit zal moeten aannemen waarin de procedureregels voor de toepassing van de bestuurlijke lus

4I Hierna: EVRM.

42 Voorstel van resolutie van 3 maart 20 ro betreffende aanbevelingen aangaande de versnelling van maatschappelijk belangrijke investeringsprojecten: Sneller door Beter, te vinden op <http:/I docs.vlaamsparlement.be/docs/stukken/2009-20Io/g395-2.pdf> (laatst geconsulteerd op 4 juli 2013). 
worden bepaald. In deze bijdrage zullen alvast mogelijke voorstellen ter zake worden besproken.

Voorwaarden om de bestuurlijke lus te gebruiken

Een vernietiging wegens de schending van een vormvereiste betekent voor de rechtszoekende soms niet meer dan een pyrrusoverwinning, omdat het bestuur, mits het formeel gebrek recht gezet wordt, opnieuw dezelfde inhoudelijke beslissing kan (lees: zal) nemen. Het voorontwerp voorziet dat een nieuw artikel in de gecoördineerde wetten op de Raad van State van 12 januari $1973^{43}$ wordt opgenomen, waarbij wordt bepaald dat de Afdeling Bestuursrechtspraak het bestuur bij tussenarrest kan opdragen om een gebrek in het bestreden besluit te herstellen of te laten herstellen. Dit is echter alleen mogelijk nadat de partijen de mogelijkheid hebben gehad hun opmerkingen te doen kennen over het gebruik van de bestuurlijke lus.

Het tussenarrest zal de wijze waarop en de termijn waarbinnen het herstel moet plaatsvinden, bepalen. Deze termijn ${ }^{44}$ zal kunnen worden verlengd op verzoek van het bestuur. Wanneer het herstel bestaat uit het nemen van een nieuw besluit, zal het voorwerp van het beroep worden uitgebreid tot dat besluit. Bovendien kan het herstel alleen de gebreken betreffen die in het arrest werden aangeduid.

De bestuurlijke lus zal wel niet kunnen worden toegepast wanneer (I) het gebrek niet herstelbaar is binnen een termijn van drie maanden, behalve als er kan worden aangetoond dat dit binnen een redelijke termijn kan geschieden ${ }^{45}$ (wat aantoont dat het voorbeeld van het arrest nr. 2I2.825 van 28 april 20II, zoals opgenomen in de toelichting bij het voorstel dat uiteindelijk het decreet van 6 juli 2012 is geworden en dat ook als voorbeeld voor de wijzigingen op federaal niveau wordt aangehaald, ongelukkig is gekozen, omdat kan worden gevreesd voor de herstelbaarheid van het gebrek binnen een termijn van drie maanden), (2) de eigen beslissingsbevoegdheid van het bestuur niet volstaat om het gebrek te herstellen, (3) het bestuur de toepassing van de herstelprocedure uitdrukkelijk weigert (het bestuur moet dus niet uitdrukkelijk om de toepassing van de herstelprocedure verzoeken), of (4) het herstel van de onwettigheid niet kan leiden tot de definitieve beslechting van het hangende geding.

Wanneer de partijen hebben verzocht om de toepassing van de bestuurlijke lus en het auditoraat en/of de Raad van State gaan niet in op dit verzoek, dan is het in dat

43 Hierna: RvS-wet.

44 In het wetsvoorstel (C. Van Cauter en P. Dewael) tot wijziging van de wetten op de Raad van State, gecoördineerd op I2 januari I973, Parl.St. Kamer 20I2-I3, nr. 2583/00I, p. I6, wordt gesteld dat de reparatietermijn wordt bepaald in functie van de concrete gegevens van de zaak ('Het spreekt voor zich dat deze termijn veel korter zal zijn voor het rechtzetten van een formeel motiveringsgebrek dan wel voor het inwinnen van een advies.').

45 Er kan worden gedacht aan de situatie waarbij de procedure de zomervakantie dient te overbruggen. 
geval aangewezen dat deze beslissing wordt gemotiveerd, zoals dit het geval is in Nederland. ${ }^{46}$

In tegenstelling tot wat het geval is voor de Raad voor Vergunningsbetwistingen wordt in het voorontwerp niet bepaald dat een voorwaarde voor de toepassing van de bestuurlijke lus is dat belanghebbenden er niet op onevenredige wijze door worden geschaad, hoewel artikel 8:51a van de Nederlandse Awb ook bepaalt dat de bestuurlijke lus niet wordt toegepast 'indien belanghebbenden die niet als partij aan het geding deelnemen daardoor onevenredig kunnen worden benadeeld'. Mogelijk ligt de moeilijkheid in het bepalen of, hoe en in welke mate niet in de procedure tussengekomen derden kunnen worden geschaad door de toepassing van de bestuurlijke lus aan de grond van de beslissing om deze voorwaarde niet op te nemen in de federale wetgeving. Of misschien was het duidelijk dat het vereiste in het decreet - zoals hiervoor aangehaald - niet langer relevant was.

Tevens kan de Raad van State, hoewel die het hoogste administratieve rechtscollege is, het bestuur niet opdragen een gebrek te herstellen, terwijl de Nederlandse Raad van State dit wel kan 'omdat tegen de uitspraak van de hoogste bestuursrechters geen rechtsmiddel openstaat en bestuurlijke vrijheid op dit punt het gezag van de hogerberoepsrechter zou aantasten'. ${ }^{47}$ Er dient evenwel te worden opgemerkt dat de Afdeling Wetgeving van de Nederlandse Raad van State hierbij bedenkingen formuleerde, omdat 'bestuursorganen om legitieme redenen een voorkeur kunnen hebben voor een nieuwe besluitvormingsprocedure in plaats van het nemen van een herstelbesluit ter uitvoering van de bestuurlijke lus'. ${ }^{8}$

Procedure om de bestuurlijke lus in te zetten

Wanneer de hervorming van de procedure voor de Raad van State in werking treedt, zullen er zich, wat betreft de bestuurlijke lus, twee mogelijkheden kunnen voordoen.

Enerzijds kan het auditoraat besluiten dat de zaak zich leent voor de toepassing van de bestuurlijke lus. In een dergelijk geval zullen de partijen, na ontvangst van het auditoraatsverslag, de mogelijkheid hebben hun opmerkingen te doen kennen over

46 Bijvoorbeeld ABRvS (NL) I9 oktober 20II, nr. 20I0I09Io/I/H2 (LJN BT8578): 'De ingevolge artikel 8:5Ia, eerste lid, van de Awb aan de rechtbank toegekende bevoegdheid een zogenoemde bestuurlijke lus toe te passen is discretionair van aard. Nu ter zitting echter uitdrukkelijk om toepassing van een bestuurlijke lus is gevraagd, diende de rechtbank voor het achterwege laten daarvan enige motivering te geven, hetgeen zij niet heeft gedaan. De Afdeling verbindt hieraan in dit geval geen gevolgen, reeds omdat het college inmiddels een nieuw besluit op het door het stadsgewest Haaglanden gemaakte bezwaar heeft genomen.'

47 E. Dans, 'Bestuurlijke lus: wondermiddel tegen lange procedures?', Kennisbank Bestuursrecht (te vinden op <www.akd.nl/media/5986r3/kennisbank\%2obestuursrecht_edans_nov2orI.pdf $>$ ), p. 4 (laatst geconsulteerd op 4 juli 20I3). Zie art. 8:5Id Awb: 'Indien de bestuursrechter in hoogste aanleg uitspraak doet, kan hij het bestuursorgaan opdragen een gebrek in het bestreden besluit te herstellen of te laten herstellen. (...)'.

48 Kamerstukken II 2007/08, 3I 352, nr. 4, p. 9-Io. 
het gebruik van de bestuurlijke lus. Indien het bestuur hiervan gebruik wenst te maken, dan zal het dit moeten meedelen in de laatste memorie. ${ }^{49}$ Gelet op de nieuwe regeling, die is ingevoerd voor de laatste memories met het koninklijk besluit van Io december 2012 tot wijziging van de artikelen I2 en I4 van het besluit van de Regent van 23 augustus 1948 tot regeling van de rechtspleging voor de Afdeling Bestuursrechtspraak van de Raad van State,,$^{50,51}$ zal het auditoraatsverslag, waarin wordt voorgesteld de bestuurlijke lus te gebruiken, eerst aan de verwerende partij en eventueel de tussenkomende partij worden meegedeeld, waardoor de verzoeker zal weten of het bestuur de bestuurlijke lus al dan niet zal aanwenden.

Anderzijds bestaat de mogelijkheid dat de toepassing van de bestuurlijke lus pas wordt voorgesteld in het tussenarrest, wat het enige geval is datwordt omschreven in het voorontwerp hoewel de eerste situatie waarschijnlijk de meest voorkomende zal zijn. Dit veronderstelt wel dat de auditeur alle middelen heeft onderzocht, wat niet steeds het geval zal zijn. Zo heeft de auditeur ex artikel 24 lid 2 RvS-wet ${ }^{52}$ de mogelijkheid om slechts die exceptie of dat middel te beoordelen die/dat de oplossing van het geschil mogelijk maakt (bijvoorbeeld de beoordeling van één middel volstaat om tot de nietigverklaring te besluiten). Indien in het verslag niet alle middelen zijn onderzocht, zal de kamer de auditeur waarschijnlijk belasten met het neerleggen van een aanvullend verslag alvorens voor te stellen de bestuurlijke lus op te starten. Dit lijkt wel niet verenigbaar met de tekst van artikel 24 lid 2 RvS-wet. Artikel 24 lid 3 RvS-wet bepaalt namelijk dat het auditoraat kan worden belast met bijkomend onderzoek '[i]ndien na toepassing van het tweede lid blijkt dat de conclusies van het verslag geen oplossing van het geschil bieden', maar de vaststelling dat de beoordeling van één middel tot de nietigverklaring van de bestreden beslissing leidt, is wel degelijk een oplossing van het geschil. De bestuurlijke lus toepassen is een andere oplossing, maar de mogelijkheid een andere oplossing te hebben voor het geschil rechtvaardigt niet dat het auditoraat op grond van artikel 24 lid 3 RvS-wet kan worden gelast met een bijkomend onderzoek teneinde een andere oplossing mogelijk te maken. Hiermee is niet gezegd dat het auditoraat die taak niet op zich zou willen nemen, maar een aanpassing van artikel $24 \mathrm{RvS}$-wet is hoe dan ook vereist.

49 Er is dus geen aparte zitting specifiek gewijd aan de bestuurlijke lus in dergelijk geval.

50 Hierna: het algemeen procedurereglement.

$5 \mathrm{I} \quad \mathrm{BS}_{4}$ februari 20I2. Zoals vroeger zullen de laatste memories opnieuw in chronologische volgorde worden gewisseld. Het komt toe aan de auditeur om in zijn verslag de volgorde te bepalen volgens dewelke het verslag aan de onderscheiden partijen moet worden betekend. Deze volgorde wordt bepaald door de inhoud van het verslag, zoals dit wordt omschreven in het verslag aan de Koning dat het koninklijk besluit voorafgaat. De hoofdregel daarbij is dat de in het ongelijk gestelde partij als eerste zijn repliek kan laten gelden.

52 Art. 24 RvS-wet luidt als volgt: '(...) In voorkomend geval kan het verslag zich beperken tot het middel van niet-ontvankelijkheid of tot het middel ten gronde dat de oplossing van het geschil mogelijk maakt. In dat geval doet de afdeling bestuursrechtspraak bij wege van arrest uitspraak over de conclusies van het verslag. Indien na toepassing van het tweede lid blijkt dat de conclusies van het verslag geen oplossing van het geschil bieden, kan de kamer in het arrest het Auditoraat gelasten, naar gelang het geval, met het onderzoek van één of meerdere welbepaalde middelen of excepties, of met het verder onderzoek van het beroep dan wel met een onderzoeksmaatregel die zij in het arrest vaststelt.' 
Wanneer pas bij tussenarrest de toepassing van de bestuurlijke lus wordt voorgesteld, beschikken de partijen over een termijn van ${ }_{5}$ dagen te rekenen van de ontvangst van het tussenarrest om hun standpunt omtrent de toepassing ervan mee te delen, waarna de Raad van State zich definitief uitspreekt over de toepassing van de bestuurlijke lus. Ook hier zal de verwerende partij, indien zij gebruik wenst te maken van de herstelprocedure, dit moeten melden. Het standpunt dat de partijen kunnen meedelen, mag wel niet worden aangewend om inhoudelijke kritiek te geven op de beoordeling door de Raad van State van de in het tussenarrest verworpen middelen. Er mag echter niet uit het oog worden verloren dat sommige middelen slechts kunnen worden onderzocht nadat de herstelprocedure heeft plaatsgehad. Zo kan de vraag of de aangevochten beslissing afdoende is gemotiveerd, of die redelijk is enzovoort, slechts worden beoordeeld in het licht van de over de zaak uitgebrachte adviezen. Wanneer de bestuurlijke lus moet worden toegepast, omdat die adviezen geheel of gedeeltelijk ontbreken, zullen dergelijke middelen slechts kunnen worden onderzocht nadat de adviezen zijn verleend.

\section{Uitvoering van het tussenarrest}

Zodra het bestuur uitvoering heeft gegeven aan het tussenarrest (dat een zo duidelijk mogelijke instructie aan het bestuur dient te omvatten, met inbegrip van de te volgen procedure), geeft het daarvan onverwijld schriftelijk kennis aan de Raad van State, alsook van de wijze waarop het gebrek is hersteld. Het lijkt niet voldoende dat het bestuur de herstelbeslissing opstuurt naar de hoofdgriffier van de Raad van State met het verzoek die toe te voegen aan het administratief dossier. Zoals dit is voorzien in artikel 39 lid 3 van het besluit van de Vlaamse Regering van I 3 juli 2012 houdende de rechtspleging voor de Raad voor Vergunningsbetwistingen, zal de herstelbeslissing door de hoofdgriffier moeten worden betekend aan de andere partijen. Die betekening zal de start van de termijn bepalen waarbinnen de andere partijen hun opmerkingen kunnen laten kennen over de wijze waarop het herstel heeft plaatsgevonden. Het voorontwerp bepaalt dat de andere partijen over 15 dagen beschikken om hun opmerkingen te laten kennen over de wijze waarop het herstel heeft plaatsgevonden.

Indien de Raad van State binnen vijftien dagen na het verstrijken van de bij tussenarrest vastgestelde hersteltermijn geen kennisgeving heeft ontvangen, wordt het bestreden besluit nietig verklaard, tenzij een van deze partijen verzoekt te worden gehoord.53 In navolging van de rechtspraak van de Nederlandse Raad van State, ${ }^{54}$

53 Er zal dan een zitting volgen waarop louter wordt onderzocht of aan de formaliteiten van het opsturen van de stukken is voldaan en of er eventueel redenen van overmacht zijn waardoor de herstelbeslissing niet tijdig kon worden opgestuurd naar de Raad van State.

54 Zie bijvoorbeeld ABRvS (NL) 2 februari 20II, nr. 200906665/I/HI, LJN BP2840, waarin werd geoordeeld als volgt: 'De op 6 januari 20II, op verzoek van [wederpartij], gehouden tweede zitting diende om nader te bezien of het besluit van 18 oktober 2010 meegenomen zou worden in de einduitspraak en het college in de gelegenheid te stellen toe te lichten waarom het de in de tussenuitspraak gestelde termijn van zestien weken ongebruikt heeft laten verstrijken. Het college heeft hierop ter zitting gesteld dat de raad eerst op 23 september 2010 over de kwestie van het 
dient de hersteltermijn te worden beschouwd als een termijn die partijen bindt. Indien de Raad van State vaststelt dat het gebrek niet volledig is hersteld of het herstel is aangetast door nieuwe gebreken, wordt het bestreden besluit of in voorkomend geval het herstellende besluit nietig verklaard, wat een ambtshalve onderzoek van de Raad lijkt in te houden. Indien het gebrek volledig is hersteld, wordt het beroep verworpen.

De vraag dient te worden gesteld of telkens een nieuwe zitting nodig is na het gebruik van de bestuurlijke lus. De Raad van State kan dezelfde procedure toepassen als in het geval dat een prejudiciële vraag wordt gesteld aan het Grondwettelijk Hof. In het tussenarrest wordt dan het door de auditeur-generaal aangewezen lid van het auditoraat ermee belast, na de ontvangst van het antwoord van het Grondwettelijk Hof op de prejudiciële vraag, het onderzoek voort te zetten. Er wordt dan een aanvullend verslag opgesteld, ${ }^{55}$ zelfs indien het Grondwettelijk Hof heeft geoordeeld dat de prejudiciële vraag ontkennend (er ligt dus geen schending voor) moet worden beantwoord. Ook bij de bestuurlijke lus zal de Raad van State het hoogstwaarschijnlijk nodig achten om het auditoraat te gelasten met een aanvullend verslag, dat vervolgens aan de partijen moet worden overgemaakt met het oog op het indienen van laatste memories. Maar er kan ernstig worden getwijfeld aan het nut van een bijkomende zitting indien het herstel er bijvoorbeeld in is gelegen de vereiste handtekening aan te brengen. Het zou dus een idee kunnen zijn om slechts in een bijkomende zitting te voorzien, indien dit uitdrukkelijk wordt verzocht door een van de partijen, waarbij zij dan ook van mening is dat de schriftelijke stukken niet volstaan voor de Raad van State om zich een oordeel te kunnen vormen over de zaak. In het andere geval zou bij verkorte procedure de bevoegde kamer zich kunnen uitspreken over de al dan niet succesvolle toepassing van de bestuurlijke lus.

Ten slotte kan nog worden opgemerkt dat, inzake artikel 4.8.4 § 2 VCRO, Boes stelt dat de bestuurlijke lus als resultaat kan hebben dat het bestuur de onregelmatigheid op een adequate wijze herstelt en een andere beslissing neemt, waarna de verzoeker op zijn beurt een beroep tot nietigverklaring kan instellen tegen de nieuwe beslissing..$^{56}$ Deze redenering gaat ook op voor de Raad van State. Hoewel het voorontwerp bepaalt dat het voorwerp van het beroep wordt uitgebreid tot het nieuwe besluit, indien het herstel bestaat uit het nemen van een nieuw besluit, bepaalt het dan weer

projectbesluit kon besluiten, omdat hij gedurende de zomerperiode met reces was. Desgevraagd heeft het op de vraag waarom het, nadat de raad bij besluit van 23 september 2010 heeft geweigerd een projectbesluit te nemen, nog tot I8 oktober 2oro heeft gewacht om een nieuw besluit op bezwaar te nemen, nadat de Afdeling het onderzoek had gesloten, gesteld dat dit te wijten was aan drukte. Deze argumenten rechtvaardigen overschrijding van de termijn niet. Dat kan slechts in zeer uitzonderlijke omstandigheden het geval zijn. De tussenuitspraak bevat, gelet op artikel 49, zesde lid, van de Wet op de Raad van State, een opdracht om het gebrek te herstellen. De daarbij gestelde termijn om aan de opdracht te voldoen, is geen termijn van orde die partijen niet bindt.'

55 Art. I3 van het algemeen procedurereglement.

56 M. Boes, 'De nieuwe procedureregels voor de Raad voor Vergunningsbetwistingen', RW 2012-I3, (II22) II3O. 
dat het herstel alleen de gebreken betreft die in het tussenarrest werden aangeduid. In tegenstelling tot de Raad voor Vergunningsbetwistingen kan de Raad van State echter, in toepassing van de bestuurlijke lus, worden geconfronteerd met een nieuw besluit, waardoor ofwel het beroep wordt uitgebreid tot het nieuw besluit, zelfs indien het gaat om een volkomen ander besluit, waarbij eventueel de Raad van State nieuwe termijnen voor het indienen en wisselen van de memories zal moeten bepalen, ofwel de oorspronkelijk bestreden beslissing samen met de nieuwe beslissing wordt vernietigd. Indien het de betrachting is van de wetgever om te vermijden dat een nieuw besluit met andere inhoud wordt genomen, dan moet dit worden verduidelijkt door te stellen dat de zuivering plaatsvindt binnen de bestreden beslissing teneinde die te handhaven. ${ }^{57}$ Kortom, is er sprake van een gewijzigde beslissing na het gebruik van de bestuurlijke lus (bijvoorbeeld de vergunning wordt wel opnieuw verleend, maar de aan de vergunning gebonden voorwaarden zijn anders), dan kan die nieuwe beslissing met een tijdig ingediend apart beroep worden aangevochten bij de Raad van State.

Daarenboven moet ook rekening worden gehouden met het reeds besproken artikel 9 van het Verdrag van Aarhus. Indien het bestuur in het kader van de toepassing van de bestuurlijke lus een nieuwe beslissing met een impact op het milieurechtelijke neemt, dan lijkt het voor een derde toch nog mogelijk om deze nieuwe beslissing aan te vechten bij de Raad van State. Volgens artikel 9 lid 2 kan de burger de rechtmatigheid van 'enig besluit, handelen of nalaten vallend onder de bepalingen van artikel 6' (in de authentieke Engelse versie: 'any decision, act or omission subject to the provisions of article 6' en in de authentieke Franse versie: 'de toute décision, tout acte ou toute omission tombant sous le coup des dispositions de l'article 6') aanvechten, waardoor een besluit genomen in het kader van de toepassing van de bestuurlijke lus niet lijkt te kunnen worden uitgesloten van het toepassingsgebied van het Verdrag van Aarhus. Ook Richtlijn 20II/92/EU bepaalt in artikel II lid I dat de lidstaten ervoor moet zorgen dat beroep kan worden ingesteld om de rechtmatigheid van 'enig besluit, handelen of nalaten vallend onder de bepalingen betreffende de inspraak van het publiek van deze richtlijn aan te vechten'.

\section{Procedure na het gebruik van de bestuurlijke lus}

In de meeste gevallen zal het voor de Raad van State aangewezen zijn om, na een correct gebruik van de bestuurlijke lus, in de overwegingen van het arrest het beroep tegen het eerste besluit niet-ontvankelijk te verklaren, terwijl het beroep tegen het herstellende besluit ongegrond wordt verklaard. Een andere mogelijkheid zou het toepassen van artikel I4ter RvS-wet zijn..$^{8}$ Hoewel bij arrest nr. I54/20I2 van

57 Amendement nr. 2 (W. Vandaele e.a.) op het voorstel van decreet houdende wijziging van diverse bepalingen van de VCRO, wat de Raad voor Vergunningsbetwistingen betreft, Parl.St. Vl.Parl. 20II-I2, nr. I509/3, 4 .

58 Art. I4ter RvS-wet luidt als volgt: 'Zo de afdeling bestuursrechtspraak dit nodig oordeelt, wijst zij, bij wege van algemene beschikking, die gevolgen van de vernietigde verordeningsbepalingen aan welke als gehandhaafd moeten worden beschouwd of voorlopig gehandhaafd worden voor 
20 december 2012 en arrest nr. I4/20I3 van 2I februari 2013 het Grondwettelijk Hof heeft geoordeeld dat het niet zonder redelijke verantwoording is de mogelijkheid van een handhaving van de gevolgen te beperken tot verordeningsbepalingen, breidt het voorontwerp die mogelijkheid toch uit tot individuele akten, waardoor een ruimere toepassing van artikel I4ter mogelijk wordt. De handhaving van de gevolgen van het vernietigd besluit is volgens het voorontwerp echter enkel mogelijk 'in uitzonderlijke omstandigheden', ingeval het beginsel van de rechtszekerheid primeert op dat van de gelijkheid. Het arrest moet ter zake een bijkomende motivering bevatten, nadat hierover een tegensprekelijk debat werd gevoerd. Na het herstel door het bestuur zou de Raad van State dan ook het beroep vooralsnog gegrond kunnen verklaren, waardoor de bestreden beslissing toch wordt vernietigd, maar de gevolgen van het vernietigde besluit handhaven. ${ }^{59}$ Zoals reeds gesteld, voorziet het voorontwerp enkel in een verwerping wanneer het gebrek volledig is hersteld, wat dan ook de toepassing van artikel I4ter RvS-wet niet mogelijk maakt, naast de vaststelling dat het artikel in België enkel kan worden toegepast 'in uitzonderlijke omstandigheden', terwijl de Nederlandse Raad van State stelt dat uit:

'een oogpunt van proceseconomie (...) het aangewezen [kan] zijn om te bepalen dat de rechtsgevolgen van het vernietigde besluit in stand blijven, indien het bestuursorgaan vasthoudt aan zijn besluit, het besluit voldoende motiveert en de andere partijen zich daarover in voldoende mate hebben kunnen uitlaten. Daarbij is beslissend of de inhoud van het vernietigde besluit na de alsnog kenbaar gemaakte motivering de rechterlijke toets kan doorstaan. ${ }^{60}$

De Nederlandse interpretatie blijkt meer ruimte te bieden voor de handhaving van de gevolgen van een vernietigd besluit, hoewel steeds rekening moet worden gehouden met het arrest C-4I/II van de Grote Kamer van het Hof van Justitie dat de instandhouding van de gevolgen van een bepaling, vernietigd wegens schending van het Unierecht, onderwerpt aan strikte voorwaarden. ${ }^{6 r}$

de termijn die zij vaststelt.' Zie o.m. F. Eggermont, 'Enkele beschouwingen inzake de toepassing van art. I4ter RvS-Wet' (noot onder RvS 29 december 20II, nr. 217.085), RW 20I2-I3, 254-257.

59 Voor de toepassing in Nederland, zie o.m. E.C. Berkouwer, 'De eerste ervaringen met de bestuurlijke lus', Gemeentestem 20Io, afl. 7345, (580) 582.

6o Zie bijvoorbeeld ABRvS (NL) 8 februari 2012, nr. 20II00587/I/A2, LJN BV3I75 (opgenomen in het Jaarverslag 2012 van de Nederlandse Raad van State). Voor een toepassing, zie ABRvS (NL) 30 juni 20I0, nr. 200904380/I/Mr, LJN BL7777.

6I In dat princiepsarrest heeft het Hof van Justitie geoordeeld dat 'gelet op de specifieke omstandigheden van het hoofdgeding' het de Raad van State 'bij uitzondering' toegestaan is een nationaal voorschrift toe te passen op grond waarvan hij bepaalde gevolgen van een nietig verklaarde nationale handeling kan handhaven wanneer (I) met deze nationale handeling naar behoren uitvoering wordt gegeven aan Richtlijn 91/676/EEG, (2) de vaststelling en inwerkingtreding van de nieuwe nationale handeling die het actieprogramma in de zin van art. 5 van Richtlijn 9I/676/EEG bevat, de uit de nietigverklaring van de bestreden handeling voortvloeiende nadelige gevolgen voor het milieu niet kunnen voorkomen, (3) de nietigverklaring van deze bestreden handeling tot gevolg zou hebben dat er met betrekking tot de uitvoering van Richtlijn 91/676/EEG een voor het milieu nadeliger rechtsvacuüm ontstaat, in die zin dat deze nietigverklaring zou resulteren in een lager niveau van bescherming van water tegen verontreiniging door nitraten uit agrarische bronnen en aldus zou indruisen tegen de wezenlijke doelstelling van deze richtlijn en (4) een uitzonderlijke handhaving van de gevolgen van een dergelijke handeling slechts de 
Wat betreft de kosten van de procedure, na toepassing van de bestuurlijke lus, lijkt het aangewezen dat bij het niet-ontvankelijk verklaren van het beroep tegen de eerste beslissing en het ongegrond bevinden van het beroep tegen de herstellende beslissing de kosten ten laste van het bestuur worden gelegd. ${ }^{62}$ De kosten van eventuele tussenkomsten blijven in beginsel ${ }^{63}$ ten laste van de tussenkomende partij.

\section{Kritiek op de bestuurlijke lus voor de Raad van State}

Aangaande de bestuurlijke lus stelt Renders, die de geregulariseerde akten na toepassing van de bestuurlijke lus definieert als genetisch gewijzigde akten, ${ }^{64}$ het volgende:

"Il y a, nous semble-t-il, dans la théorie du retrait d'acte, tout ce que la "boucle administrative" néerlandaise présente d'avantages. Une critique doit cependant être formulée à l'encontre de ce mécanisme, que la théorie du retrait n'a pas à essuyer; toute irrégularité, même de forme, touche au fond de la décision; l'auteur d'un acte n'est pas l'autre; une formalité est faite pour éclairer l'auteur; seule une motivation adéquate peut valablement conduire au dispositif d'une décision etc.

En permettant à l'administration de corriger, au dernier moment, une irrégularitétenant à la légalité externe de l'acte, l'on fait fi de l'interaction qui existe entre la forme d'une décision et le fond de celle-ci, qui fait de la compétence de l'auteur de l'acte, des formes et des formalités, non du formalisme, mais une composante essentielle du fondement de l'action administrative. ${ }^{65}$

De wetgever dwingt de Raad van State om niet enkel te kijken naar de rechtsbescherming van de burger, maar om tevens rekening te houden met een efficiënt overheidsoptreden.

Vooreerst bestaat natuurlijk het gevaar dat de bestuurlijke lus leidt tot een verminderde aandacht van het bestuur voor wat betreft de kwaliteit van zijn beslissingen. Ingeval een vernietigingsberoep wordt ingesteld tegen een niet-gemotiveerde beslissing of een beslissing die werd genomen zonder eerst het vereiste advies in te

periode betreft die absoluut noodzakelijk is om de maatregelen vast te stellen waarmee de vastgestelde onregelmatigheid kan worden verholpen.

62 Voor een gelijkaardige situatie, wat betreft de Raad voor Vergunningsbetwistingen, zie art. 4.8.28 $\$ 2$ lid 3 VCRO: 'Indien toepassing wordt gemaakt van artikel 4.8.4 of artikel 4.8.5, dan kan de Raad, in afwijking van het eerste lid, de kosten geheel of gedeeltelijk ten laste van het vergunningverlenende bestuursorgaan leggen.'

63 In het arrest nr. 221.647 van 6 december 2012 oordeelde de Raad van State dat de verwerende partij had gehandeld in strijd met wat een passende rechtsbescherming tegen onwettig overheidsoptreden diende in te houden. Hoewel de kosten verbonden aan de vrijwillige tussenkomst in beginsel ten laste van de tussenkomende partij worden gelegd, vond de Raad van State dat de houding van de verwerende partij verantwoordde dat zij ook werd veroordeeld tot de kosten die verband hielden met de vrijwillige tussenkomst.

64 Of A.G.M. ('des actes génétiquement modifiés'), zie 'Intervention de David Renders et de Benoit Gors' in Publicum juni 2013, 29.

65 Voorwoord van D. Renders in: Ph. Bouvier, La naissance du Conseil d'Etat de Belgique: une histoire française?, Brussel: Bruylant 20I2, p. 2I. 
winnen, kan een dergelijke fout worden rechtgezet in de loop van de procedure voor de Raad van State. Dit gegeven kan niet enkel aanleiding geven tot slordigheid, maar eventueel zelfs tot misbruik van de wil van de wetgever om soepeler om te gaan met bepaalde schendingen van het recht, zoals de schending van vormvereisten. Het bestuur zou ervoor kunnen opteren om in bepaalde omstandigheden de vereiste procedures niet te doorlopen en pas wanneer beroep wordt ingesteld bij de Raad van State over te gaan tot het naleven van de opgelegde procedure.

De vraag dient ook te worden gesteld of de Raad van State (en dus ook het auditoraat) gewoon niet anders moet omgaan met een vastgestelde schending van een vormvereiste. In Opinie nr. I5 van de Consultative Council of European Judges, aangenomen te Parijs op 6 november 20I2, werd gesteld dat rechters dienen te oordelen gesteund op hun 'general knowledge of the law and its underlying principles, their common sense and knowledge of the realities of life' ${ }^{66}$ Hierbij kan worden verwezen naar het arrest nr. 335.033 van 23 december $201 \mathrm{I}$ inzake Danthony van de algemene vergadering van de Franse Raad van State, waarin werd geoordeeld dat:

'un vice affectant le déroulement d'une procédure administrative préalable, suivie à titre obligatoire ou facultatif, ${ }^{67}$ n'est de nature à entacher d'illégalité la décision prise que s'il ressort des pièces du dossier qu'il a été susceptible d'exercer, en l'espèce, une influence sur le sens de la décision prise ou qu'il a privé les intéressés d'une garantie; que l'application de ce principe n'est pas exclue en cas d'omission d'une procédure obligatoire, à condition qu'une telle omission n'ait pas pour effet d'affecter la compétence de l'auteur de l'acte.'

Hiermee heeft de Franse Raad van State een minder formalistische houding aangenomen, en heeft hij de rechtszekerheid boven de wettelijkheid geplaatst, ${ }^{68}$ hoewel de relativiteitsprincipes geformuleerd in het arrest Danthony in het concrete geval de nietigverklaring niet hebben kunnen verhinderen. Ook de voorzitter van de Afdeling Bestuursrechtspraak van de Nederlandse Raad van State, Polak, heeft, samen met Roelfsema, gewezen op 'de grote maatschappelijke behoefte om een eind te maken aan een te procedureel gerichte bestuursrechtspraak' ${ }^{69}$ en Pacteu spreekt over 'un signe de maturité de notre justice administrative comme de sa maîtrise de l'action publique'. ${ }^{\circ}$

66 Overweging 26, te vinden op <https://wcd.coe.int/ViewDoc.jsp?Ref=CCJE(2012)4\&Language=1 anEnglish\&Ver=original\&BackColorInternet=DBDCF2\&BackColorIntranet=FDC864\&BackCol orLogged=FDC864> (laatst geconsulteerd op 6 juli 2013).

67 Voor een kritiek op het onderscheid tussen verplicht en facultatief advies dat bijwijlen wordt gemaakt, zie X. Domino en A. Bretonneau, 'Chronique générale de jurisprudence administrative française', AJDA 6 februari 20I2, p. I95 e.v.

68 F. Melleray, noot onder RvS (FR) 23 december 20II, nr. 335.033, Danthony e.a., Revue mensuelle Lexisnexis Jurisclasseur 2012 (maart), (29) 30.

69 J. Polak en J. Roelfsema, 'Het streven van de Afdeling bestuursrechtspraak van de Raad van State naar effectieve en finale geschilbeslechting', Bestuurswetenschappen 20I2, nr. 5, (64) 67 .

70 B. Pacteau, noot onder RvS (FR) 29 juni 2012, nr. 335.771, Association Promouvoir e.a., AJDA 22 oktober 2012, (I957) I959. 
Het standpunt ingenomen in het arrest Danthony vormt de aanleiding voor het voorstel tot opname in de Belgische wetgeving (toevoeging van een lid aan artikel I4 $§$ I RvS-wet volgens het voorontwerp) van het volgende uitgangspunt: de vraag dient te worden gesteld of in het concrete geval de schending van het vormvereiste de inhoud van de eindbeslissing heeft kunnen beïnvloeden of, rekening houdende met het verloop van de procedure, de belanghebbenden van een waarborg heeft kunnen onthouden, of de bevoegdheid van de steller van de handeling kunnen aantasten..$^{71}$ Dit beginsel vinden we vandaag evenwel al terug in buitenlandse wetgeving, zoals bijvoorbeeld in:

I. $\$ 46$ van het Duitse Verwaltungsverfahrensgesetz van 25 mei 1976 , dat stelt dat een administratieve rechtshandeling niet kan worden vernietigd om de enkele reden dat die niet werd aangenomen in overeenstemming met de procedureregels, wanneer het duidelijk is dat de schending de inhoud van de beslissing niet heeft beïnvloed $;^{72}$

2. artikel 2Iocties.2 van de Italiaanse wet van 7 augustus I990, nummer 24I, dat stelt dat een beslissing niet kan worden vernietigd wegens schending van een vormvereiste indien het duidelijk is dat de uitkomst van de herstelbeslissing gelijk zou zijn aan de genomen beslissing;

3. artikel 63.2 van de Spaanse wet nr. 30/1992 van 26 november 1992, dat stelt dat de schending van een vormvereiste enkel tot nietigverklaring leidt indien de vormvereisten noodzakelijk waren om het doel van de akte te bereiken of indien belanghebbenden zich niet hebben kunnen verdedigen;73

4. artikel 70 van de Franse wet nr. 20II-525 van 17 mei 20II, dat stelt dat "[l]orsque l'autorité administrative, avant de prendre une décision, procède à la consultation d'un organisme, seules les irrégularités susceptibles d'avoir exercé une influence sur le sens de la décision prise au vu de l'avis rendu peuvent, le cas échéant, être invoquées à l'encontre de la décision.'

Het beantwoorden van de vraag of de schending van een bepaald vormvereiste nu al dan niet invloed heeft gehad op de uiteindelijk genomen beslissing is natuurlijk moeilijk en kan drastisch verschillen van magistraat tot magistraat. Zo is het alvast typerend dat in het arrest Danthony de rapporteur public de mening was toegedaan dat er geen aanwijzingen waren van dergelijke invloed. ${ }^{74}$ Hierbij kan tevens worden verwezen naar het standpunt van Mialot die stelt:

7I Zie ook: J.B. Auby, 'Irrégularités procédurales', Droit administratif-Revue mensuelle du Jurisclasseur 2012 (maart), (I) I.

72 \$ 6 VwVfG: 'Die Aufhebung eines Verwaltungsaktes, der nicht nach § 44 nichtig ist, kann nicht allein deshalb beansprucht werden, weil er unter Verletzung von Vorschriften über das Verfahren, die Form oder die örtliche Zuständigkeit zustande gekommen ist, wenn offensichtlich ist, dass die Verletzung die Entscheidung in der Sache nicht beeinflusst hat.'

73 Art. 63.2 Ley 30/1992 de Régimen Jurídico de las Administraciones Públicas y del Procedimiento Administrativo Común: 'No obstante, el defecto de forma sólo determinará la anulabilidad cuando el acto carezca de los requisitos formales indispensables para alcanzar su fin o dé lugar a la indefensión de los interesados.'

74 C. Broyelle, 'L'impact du vice de procédure sur la légalité de l'acte administratif', La Semaine Juridique Administrations et Collectivités territoriales 2 april 2012, 2089, § 3 (geraadpleegd via <www. 
'Plus la marge d'appréciation du juge est importante dans l'application du droit, plus sa position devient sensible au regard de ces autorités élues lorsqu'il décide d'annuler une décision administrative: lorsque le juge s'abrite derrière la technique juridique pour annuler un acte, il est "couvert" par le droit et la technique.

(...)

Cependant, il s'agit sans doute de la conséquence la plus fâcheuse de cet arrêt, dès lors qu'il appartient dorénavant au juge, au cas par cas, selon les espèces, de définir quel vice dans la procédure est de nature à entraîner l'illégalité de la décision, nous doutons sérieusement que la lisibilité de l'ordre juridique et donc la sécurité juridique y gagneront'75

In plaats van de procedure voor de Raad van State opnieuw te verzwaren met de bestuurlijke lus, zou een beter gebruik moeten worden gemaakt van de mogelijkheid die wordt geboden door het feit dat er in België een auditoraat in de Raad van State bestaat. Nu reeds bepaalt artikel I2 van het algemeen procedurereglement voor de Raad van State dat, met het oog op het opmaken van het verslag, de auditeur rechtstreeks briefwisseling voert met alle overheden en besturen en dat hij zowel aan hen als aan de partijen alle dienstige inlichtingen en documenten kan vragen. De auditeur kan, volgens dat artikel, de partijen zelfs een termijn opleggen voor het verstrekken van de gevraagde inlichtingen en documenten. Indien deze niet binnen de gestelde termijn worden meegedeeld, dan stelt de auditeur, 'hiermee rekening houdende', zijn verslag op. Deze tussenkomst van de auditeur zou kunnen worden uitgebreid tot een soort 'informele bestuurlijke lus' die in Nederland al werd aangewend nog vóór de opname van de bestuurlijke lus in de Awb. Gedurende het vooronderzoek kan de rechter het bestuur wijzen op een gebrek, onder meer in een beslissing tot schorsing ${ }^{76}$ of heropening van het onderzoek..$^{77}$ Vandaag blijft in Nederland de mogelijkheid van de informele bestuurlijke lus, naast de wettelijke bestuurlijke lus, bestaan. ${ }^{7}$ Het auditoraat kan gebruikmaken van de informele bestuurlijke lus in het onderzoek van de zaak. Indien de met de zaak belaste auditeur bijvoorbeeld vaststelt dat een bepaald advies niet werd ingewonnen en dat dit vormgebrek aanleiding zal geven tot de conclusie in het verslag dat de bestreden beslissing moet worden vernietigd, zou hij het bestuur kunnen aanschrijven met het verzoek alsnog het vereiste advies voor te leggen. Op die manier kan het auditoraat er voor zorgen dat de zaak finaal wordt beslecht zonder toepassing te maken van de formele bestuurlijke lus, want in het auditoraatsverslag kan nu de verwerping worden voorgesteld, gelet op het indienen van het vereiste advies,$^{79}$ waarna het aan de verzoeker toekomt om al

lexisnexis.com>), waarin wordt gesteld: 'L'impact potentiel d'un vice ne se constate pas; il se décide.'

75 C. Mialot, 'L'arrêt Danthony du point de vue du justiciable', AJDA 20I2, I487-I488.

76 Art. 8:64 Awb.

77 Art. 8:68 Awb.

78 E. Dans, 'Bestuurlijke lus: wondermiddel tegen lange procedures?', Kennisbank Bestuursrecht (te vinden op <www.akd.nl/media/5986I3/kennisbank\%2obestuursrecht_edans_nov2orI.pdf>), p. 6.

79 Dit voorbeeld gaat er wel van uit dat het advies in overeenstemming is met de uiteindelijk aangevochten beslissing. 
dan niet over te gaan tot de voortzetting van de procedure. ${ }^{80}$ Indien tot voortzetting wordt overgegaan, moet de verzoeker wel in de gelegenheid worden gesteld om zich uit te spreken over het nieuwe advies of stuk, wat echter kan via de wisseling van de laatste memories na het auditoraatsverslag. Een 'actieve' rol van het auditoraat zou alvast in de lijn leggen met wat Dans voorstelt voor Nederland:

'De bestuurlijke lus zou mogelijk nog efficiënter kunnen worden ingezet indien de rechter eerder in de procedure de vinger op de zere plek zou leggen en het bestuursorgaan eerder in de gelegenheid zou stellen om het gebrek te herstellen. De rechter zou het middel bijvoorbeeld vaker dan nu het geval is al tijdens het vooronderzoek, voor dat het onderzoek ter zitting is begonnen, kunnen toepassen. ${ }^{81}$

De voormelde werkwijze, via het auditoraat, komt alvast tegemoet aan de vaste rechtspraak van het Europees Hof voor de Rechten van de Mens inzake het recht te worden gehoord door de rechter. ${ }^{82}$ Indien de verzoeker niet akkoord gaat met het voorgelegde advies en de herstelbeslissing, dan kan hij dit uiten via de laatste memorie, waarna hij kan worden gehoord ter terechtzitting. ${ }^{8}{ }_{3}$ Bovendien kan de Raad voor Vergunningsbetwistingen bij tussenarrest de bestuurlijke lus aanwenden nog vóór een zitting heeft plaatsgevonden, ${ }^{84}$ waardoor een toepassing door het auditoraat vóór een zitting ook mogelijk zou moeten zijn.

Tevens kan de invoering van het relativiteitsvereiste in de procedure voor de Raad van State soelaas bieden. Artikel I.9 van de Nederlandse Crisis- en herstelwet van I8 maart 20I0, dat sinds I januari 2013 niet meer in werking is, bepaalde dat de administratieve rechter een besluit niet vernietigde op grond 'dat het in strijd is met een geschreven of ongeschreven rechtsregel of een algemeen rechtsbeginsel, indien deze regel of dit beginsel kennelijk niet strekt tot bescherming van de belangen van degene die zich daarop beroept. ${ }^{15}$ Ook artikel 6:22 van de Nederlandse Awb, zoals gewijzigd door de wet van 20 december $2012,{ }^{86}$ stelt dat een besluit waartegen bezwaar is gemaakt of beroep is ingesteld, ondanks 'schending van een geschreven of ongeschreven rechtsregel of algemeen rechtsbeginsel', door het orgaan dat op het

8o Onduidelijkheid in het besluit van het auditoraatsverslag is niet aanvaardbaar. Er mag dan ook niet worden besloten tot verwerping 'op voorwaarde van het overleggen van het vereiste advies' bijvoorbeeld. Het auditoraat zou dus de informele bestuurlijke lus moeten hebben doorlopen vóór het opstellen van het verslag, waarna tot een ondubbelzinnig besluit moet worden gekomen.

8I E. Dans, 'Bestuurlijke lus: wondermiddel tegen lange procedures?', Kennisbank Bestuursrecht, p. I3.

82 EHRM 23 februari I994, nr. I8928/9I (Fredin t. Zweden (No. 2)): 'The Court is of the view that, in such circumstances at least, Article 6 para. I (art. 6-I) guarantees a right to an oral hearing. Accordingly, the refusal by the Supreme Administrative Court to hold an oral hearing in the applicant's case constituted a violation of Article 6 para. I (art. 6-I) of the Convention.'

83 Ook de Nederlandse Afdeling Wetgeving heeft, wat betreft de bestuurlijke lus, gewezen op het belang om argumenten tegen de wijze van herstel mondeling naar voren te kunnen brengen (Kamerstukken II 2007/08, 3I 352, nr. 4, p. 7).

84 Parl.St. Vl.Parl. 20II-I2, nr. I509/I, p. 9.

85 Zie ook B. Schueler, 'Een relativiteitsleer in wording', NTB 20II, nr. 9, p. 265-27I.

86 Stb. 2012, 682. 
bezwaar of beroep beslist in stand kan worden gelaten indien aannemelijk is dat de belanghebbenden daardoor niet zijn benadeeld.

Voorts moet worden vastgesteld dat in Vlaanderen de bestuurlijke lus werd ingevoerd wegens de achterstand die bestaat bij de Raad voor Vergunningsbetwistingen, en wat betreft de Raad van State, wegens de ontevredenheid die ontstond in Vlaanderen wegens enkele ophefmakende arresten die nog het gevolg waren van de historische achterstand bij de Raad van State. Heden bestaat de achterstand bij (alvast de Nederlandstalige afdelingen van) het auditoraat en de kamers niet meer, waardoor de principiële doelstelling van de wijzigingen aan de bevoegdheden van en procedure voor de Raad van State van weinig meerwaarde is, indien de Raad van State in staat is om tijdig zijn arresten te wijzen, wat door de burgerlijke rechtbank te Brussel werd gekwalificeerd als een resultaatsverbintenis. ${ }^{87}$ Nieuwigheden in het voorontwerp zoals de vervanging van het begrip 'moeilijk te herstellen ernstig nadeel' in 'spoedeisendheid' om de tenuitvoerlegging van een beslissing te kunnen schorsen, waarbij de vordering tot schorsing te allen tijde in de loop van de procedure zal kunnen worden ingesteld (in tegenstelling tot vandaag waarbij de schorsing en nietigverklaring in een en hetzelfde verzoekschrift dienen te worden ingesteld), ${ }^{88}$ doen alvast vrezen dat dit een negatieve weerslag zal hebben op de doorlooptijd van de zaken. Ook de verplichting aan Belgische kant - in tegenstelling tot de Nederlandse regelgeving - om eerst alle middelen te beoordelen vooraleer kan worden overgegaan tot het gebruik van de bestuurlijke lus, zal een dergelijk negatief effect bewerkstelligen. Vandaag gaat het auditoraat namelijk vaak over tot het opstellen van een verslag ex artikel 24 lid 2 RvS-wet, waarbij het beroep gegrond wordt bevonden, gelet op de schending van het vormvereiste, zonder de overige middelen te bespreken. Het voordeel hiervan is, ook gelet op de 'haast wonderbare versnelling's9 van het procedureverloop voor de Raad van State, dat de partijen snel een onwettigheid zien geïdentificeerd door het auditoraat, waarna het bestuur onmiddellijk de gepaste maatregelen kan treffen om aan de onwettigheid een einde te maken. De voorzitter van de Raad van State is wel de mening toegedaan dat artikel $24 \mathrm{RvS}$-wet dient te worden herzien, zodat het auditoraat steeds alle middelen onderzoekt 'teneinde meerdere gedingen of zelfs carrousels te vermijden'. ${ }^{\circ}$ Het valt evenwel ernstig te betwijfelen dat een meerderheid in het auditoraat die idee genegen is.

Er zullen zich ten slotte situaties voordoen waarin verscheidene malen in dezelfde zaak toepassing zal worden gemaakt van de bestuurlijke lus. Stel dat de gouverneur tot intrekking van een wapenvergunning is overgegaan, wat uiteindelijk in administratief beroep werd bevestigd door de minister van Justitie. Het auditoraat stelt vast dat de intrekking heeft plaatsgevonden met miskenning van de hoorplicht als

87 Rb. Brussel I5 oktober 2009, JT 20I0, I95.

88 Art. I7 \$ 3 RvS-wet.

89 Zoals omschreven door de voorzitter van de Vlaamse Juristenvereniging in: F. Judo, 'Graag traag?', RW 2012-13, I358.

90 P. Lefranc, 'De toegang tot de afdeling bestuursrechtspraak van de Raad van State in het licht van het Verdrag van Aarhus', TMR 2012/6, (634) 637. 
beginsel van behoorlijk bestuur. Bij tussenarrest wordt de minister van Justitie de mogelijkheid gegeven om de betrokkene te horen, waarna eventueel een herstelbeslissing wordt genomen. Indien de beslissing wordt hersteld, dan kan de verzoeker nieuwe middelen die betrekking hebben op dit herstel opwerpen. Zo kan hij onder meer opwerpen dat de herstelbeslissing door de kabinetschef van de minister is ondertekend en niet door de minister van Justitie zelf. Indien het auditoraat het standpunt van de verzoeker bijtreedt, kan opnieuw de toepassing van de bestuurlijke lus worden voorgesteld, maar dit veronderstelt uiteraard dat de eventuele nieuwe middelen eerst worden onderzocht. Bij tussenarrest kan dan opnieuw de minister de mogelijkheid krijgen om een herstelbeslissing te nemen die ditmaal correct is ondertekend. Het spreekt voor zich dat hierdoor de doorlooptijd van een zaak zal toenemen. In Marseille en Sietses wordt dan ook opgeroepen om terughoudend te zijn in het gebruik van de bestuurlijke lus totdat meer bekend is aangaande de verhouding tussen de duur van de vertraging in de afhandeling van het beroep door de rechter en de duur van de verlengde besluitvorming ingeval van een kale vernietiging..$^{\text {I }}$

\section{Toepassingen van de bestuurlijke lus door de Raad van State}

In dit hoofdstuk wordt onderzocht in welke mogelijke situaties de Raad van State al dan niet kan gebruikmaken van de bestuurlijke lus. ${ }^{92}$ Het is hierbij interessant op te merken dat in Marseille en Sietses aangaande de praktijk van de Nederlandse Raad van State het volgende wordt gesteld:

'Al met al is er weinig lijn te ontdekken in de beslissingen van de Afdeling bestuursrechtspraak over toepassing van de bestuurlijke lus. Voor zover de keuze op beleid is gebaseerd, hebben wij het daaraan ten grondslag liggende criterium niet kunnen ontdekken. ${ }^{93}$

Marseille en Sietses besluiten dan ook dat de toepassing van de bestuurlijke lus afhangt van niets anders dan ... het toeval, ${ }^{94}$ maar het is uiteraard mogelijk dat er binnen de Nederlandse Raad van State bepaalde maatstaven voor het gebruik van de bestuurlijke lus voorhanden zijn die niet bekend zijn ten gevolge van het geheim van het beraad. Zij stellen ook vast dat de Afdeling Bestuursrechtspraak van de Nederlandse Raad van State in bijna acht van de tien gevallen, waarin de keuze voor de bestuurlijke lus aan de orde is, beslist die niet toe te passen (hoewel natuurlijk ook kan worden geargumenteerd dat in twee van de tien gevallen de bestuurlijke lus toepassen, eerder veel is). ${ }^{95}$ 


\section{I Enkele gevallen waarin de bestuurlijke lus niet mogelijk lijkt}

Er dient te worden opgemerkt dat de bestuurlijke lus niet kan worden toegepast in de gevallen waarin de overheid niet beschikt over een discretionaire bevoegdheid en de overheid bij nietigverklaring van de bestreden beslissing niet anders kan dan dezelfde beslissing nemen. In dergelijke gevallen zal de Raad van State gewoon vaststellen dat de verzoeker niet beschikt over het rechtens vereiste belang bij het beroep tot nietigverklaring. Het is ook niet wenselijk dat de Raad van State de bestuurlijke lus voorstelt in een zaak waarin het voor de Raad duidelijk is dat een heroverweging tot een volkomen andere beslissing kan leiden (bijvoorbeeld een anders samengesteld orgaan na verkiezingen en het hierna besproken arrest nr. 222.969 van 25 maart 2013 van de Raad van State).

Tevens kan worden gedacht aan de schending van vormvereisten in het kader van een pacificatiemodel. De burgemeester van een gemeente gelegen in het Vlaamse Gewest wordt door de Vlaamse Regering benoemd voor een periode van zes jaar uit de verkozenen voor de gemeenteraad na een voordracht door de gemeenteraad aan de provinciegouverneur. Wat betreft de benoeming van burgemeesters in de randgemeenten (Vlaamse Rand rond het Brussels Hoofdstedelijk Gewest) ${ }^{96}$ is echter een bijzondere procedure uitgewerkt, met de bijzondere wet ${ }^{97}$ van I9 juli $2012 .^{8}$

Ingeval van betwisting wordt de zaak beslecht door de algemene vergadering van de Afdeling Bestuursrechtspraak. Indien de algemene vergadering, die wat deze geschillen betreft afwisselend wordt voorgezeten door de eerste voorzitter en de voorzitter van de Raad van State, ${ }^{99}$ de beslissing tot weigering bevestigt, dan is de beslissing tot niet-benoeming definitief. ${ }^{\text {100 }}$ Ingeval de algemene vergadering de beslissing tot weigering tenietdoet (bij staking der stemmen is de stem van degene die de algemene vergadering voorzit beslissend), leidt het arrest tot de definitieve benoeming van de aangewezen-burgemeester en tot zijn vervanging als schepen.

96 Drogenbos, Kraainem, Linkebeek, Sint-Genesius-Rode, Wemmel en Wezembeek-Oppem.

97 Een bijzondere wet wordt aangenomen met de in art. 4, in fine, Gw. bepaalde meerderheid, namelijk: een wet, aangenomen met de meerderheid van de stemmen in elke taalgroep van elke Kamer, op voorwaarde dat de meerderheid van de leden van elke taalgroep aanwezig is en voor zover het total van de ja-stemmen in beide taalgroepen twee derden van de uitgebrachte stemmen bereikt.

98 Bijz.W. van I9 juli 2012 houdende wijziging van de wet van 9 augustus 1988 tot wijziging van de gemeentewet, de gemeentekieswet, de organieke wet betreffende de ocmw's, de provinciewet, het Kieswetboek, de wet tot regeling van de provincieraadsverkiezingen en de wet tot regeling van de gelijktijdige parlements- en provincieraadsverkiezingen (de zogenoemde 'pacificatiewet') en van de bijzondere wet tot hervorming der instellingen, wat de benoeming van de burgemeesters van de zes randgemeenten betreft, BS 22 augustus 20I2; inwerkingtreding op I4 oktober 2012.

99 De eerste voorzitter en de voorzitter van de Raad van State moeten tot een verschillende taalrol behoren.

Ioo De gemeenteraad beschikt dan over dertig dagen om door een stemming een nieuwe voordrachtsakte te bevestigen. 
In het advies van de Afdeling Wetgeving van de Raad van State over het voorstel, dat uiteindelijk voormelde bijzondere wet werd, wordt het volgende opgemerkt:

'Luidens het voorgestelde artikel 13/1, $\$ 7$, leidt het arrest van de algemene vergadering van de afdeling Bestuursrechtspraak van de Raad van State waarbij de beslissing tot weigering tot benoeming "teniet wordt gedaan", tot de definitieve benoeming van de aangewezen burgemeester en tot zijn vervanging als schepen volgens de procedure bedoeld in artikel 15, § 2, (van de Nieuwe Gemeentewet) indien hij als schepen was verkozen. De Raad van State vestigt er de aandacht op dat de voorgestelde bepaling ertoe kan leiden dat, zelfs wanneer het arrest van de algemene vergadering waarbij de weigering van de benoeming tot burgemeester wordt "tenietgedaan" zijn grondslag vindt in een vormgebrek, die benoeming definitief wordt. Vraag is of dit werkelijk de bedoeling is. ${ }^{101}$

In de Kamercommissie voor de herziening van de Grondwet en de hervorming van de instellingen diende Kamerlid Ben Weyts (N-VA) nog een amendement in dat ertoe strekte te bepalen dat, ingeval de Raad van State de beslissing om de benoeming van de burgemeester te weigeren verbreekt, het benoemingsdossier wordt overgezonden aan de Vlaamse Regering, die in voorkomend geval een nieuwe beslissing kan nemen of de al genomen beslissing met andere redenen kan omkleden, ${ }^{102}$ wat een wettelijk georganiseerde vorm van bestuurlijke lus zou hebben ingehouden. Zodoende zou een vernietiging op basis van een vormgebrek niet automatisch leiden tot benoeming van de burgemeester. Dit amendement werd echter verworpen. ${ }^{\text {103 }}$ Op de vraag gesteld door de Afdeling Wetgeving of het werkelijk de bedoeling is dat bij tenietdoen van de weigering tot benoeming van de aangewezen-burgemeester wegens een vormgebrek laatstgenoemde definitief tot burgemeester wordt benoemd, dient dan ook bevestigend te worden geantwoord, wat door staatssecretaris voor Staatshervorming Wathelet uitdrukkelijk werd bevestigd. ${ }^{104}$ De staatssecretaris voegde er echter nog het volgende aan toe:

'In dat opzicht moet worden gepreciseerd dat de Raad van State een uitspraak zal doen over de wettigheid van de beslissingen tot weigering onder identieke voorwaarden als die die van toepassing zijn op het vernietigingscontentieux, op grond van de gecoördineerde wetten en zijn jurisprudentie. Het gaat onder meer om de gevallen waarin de Raad van State beslist om een vormfout al dan niet te sanctioneren. ${ }^{105}$

In het 'normale' vernietigingscontentieux, dat 'onder identieke voorwaarden' van toepassing is op de procedure inzake de benoeming van de burgemeester in de randgemeenten, leidt niet om het even welke vormfout, maar alleen de schending van vormvereisten die 'substantieel of op straffe van nietigheid voorgeschreven' zijn,

IOI Adv.RvS 5I.2I6/AV van 2 mei 20I2, Parl.St. Senaat 20II-I2, nr. I565/2, p. 8.

I02 Verslag namens de commissie voor herziening van de Grondwet en de hervorming van de instellingen, Parl.St. Kamer 20II-I2, nr. 2284/003, p. 47.

I03 Parl.St. Kamer 20II-I2, nr. 2284/003, p. 52.

ro4 Verslag namens de Commissie voor de Institutionele Aangelegenheden uitgebracht door de heren De Decker en Beke, Parl.St. Senaat 20II-I2, nr. I562/4, p. 29.

I05 Parl.St. Senaat 20II-I2, nr. I562/4, p. 29. 
tot vernietiging. ${ }^{106}$ Wanneer de algemene vergadering van de Raad van State in de beslissing van de Vlaamse Regering om de aangewezen burgemeester niet te benoemen een schending van een vormvereiste vaststelt, dan zal die niet, in het licht van de doelstelling van de pacificatieprocedure voor de algemene vergadering, kunnen worden rechtgezet door gebruik te maken van de bestuurlijke lus, omdat het voorontwerp het gebruik van de bestuurlijke lus in het kader van een procedure gesteund op een bijzondere wet uitdrukkelijk uitsluit. Het nemen van een beslissing door de Vlaamse Regering, behept met een vormgebrek, wordt in het contentieux van de benoeming van de burgemeesters van de randgemeenten namelijk beschouwd als dé oplossing voor een heikel Belgisch communautair probleem. ${ }^{\text {107 }}$

In de reeds hangende gedingen voor de algemene vergadering van de Afdeling Bestuursrechtspraak, ingesteld door twee aangewezen-burgemeesters, had de Vlaamse Regering aan de algemene vergadering gevraagd om een prejudiciële vraag te stellen aan het Grondwettelijk Hof omdat naar haar mening de beginselen van gelijkheid en niet-discriminatie, zoals vervat in de artikelen Io en II Gw., zijn geschonden in zoverre daarbij de benoeming, door de Vlaamse Regering, van de burgemeesters van de randgemeenten en de bescherming die de Vlaamse Regering aan de inwoners van de randgemeenten kan bieden, alsmede de betwisting van die benoeming, anders worden geregeld dan de benoeming, door die Regering, van burgemeesters van de andere Vlaamse gemeenten, alsmede de betwisting van die benoeming, voor zover de weigering tot benoeming wordt tenietgedaan wegens een externe illegaliteit in het algemeen of een vormgebrek in het bijzonder en de aangewezen-burgemeester hierdoor definitief wordt benoemd. De aangewezenburgemeesters wierpen evenwel op dat de gesuggereerde prejudiciële vraag nietontvankelijk was, omdat geen enkele bepaling van de bijzondere wet van ig juli 2012 uitdrukkelijk toelaat dat de bestreden weigering tot benoeming wordt tenietgedaan omwille van een vormgebrek. De algemene vergadering heeft die exceptie verworpen, omdat de gesuggereerde prejudiciële vraag de grondwettigheid betreft van de nieuwe benoemingsprocedure van de burgemeesters in de randgemeenten in haar geheel, waardoor zij aldus aan de bevoegdheid van de algemene vergadering raakt om van het geschil kennis te nemen als zodanig en zodoende heeft zij niet alleen betrekking op de situatie dat de weigering tot benoeming wordt tenietgedaan omwille van een vormgebrek. Bovendien, aldus de algemene vergadering, wordt het wettigheidstoezicht op de weigering tot benoeming, op grond van artikel I 3 bis $\$ 5$ van de nieuwe gemeentewet, uitgeoefend 'onder identieke voorwaarden als die welke van toepassing zijn op het vernietigingscontentieux, op grond van de

Io6 Zie ook J. Velaers, 'De eerste fase van de zesde staatshervorming (deel I)', RW 20I2-I3, (IOO2) I027, en S. Denys, 'Naar snellere en efficiëntere advisering bij grote infrastructuurprojecten', TBP 2010, (588) 603 e.v.

Io7 Het is ten slotte interessant op te merken dat vice-Eerste Minister Vande Lanotte in een interview in Le Soir van 28 januari 2013 de opheffing van de taalpariteit op het niveau van het Brussels Hoofdstedelijk Gewest (ten nadele van de Vlaamse mandatarissen) verdedigde in ruil voor een controle op de naleving op de taalwetgeving door administratieve rechtscolleges in plaats van een politieke controle. 
gecoördineerde wetten en zijn jurisprudentie'. ${ }^{108}$ Het wettigheidstoezicht heeft bijgevolg ook betrekking op de naleving van substantiële of op straffe van nietigheid voorgeschreven vormen. De algemene vergadering is dan ook overgegaan tot het stellen van de prejudiciële vraag, zoals dit ook werd geadviseerd door het auditoraat, waardoor het nu wachten is op een uitspraak van het Grondwettelijk Hof.

Indien het Grondwettelijk Hof bevestigend antwoordt op de prejudiciële vraag, dan zullen de beginselen van gelijkheid en niet-discriminatie ook worden geschonden doordat de Vlaamse Regering bij de benoeming van burgemeesters van gemeenten in het Vlaamse Gewest wel mag gebruikmaken van de bestuurlijke lus en voor de benoeming van burgemeesters en schepenen van andere gemeenten niet. Het feit dat artikel I29 \$ 2 Gw. stelt dat de decreten van de Vlaamse Gemeenschap inzake taalregeling geen kracht van wet hebben in de laatstgenoemde gemeenten die grenzen aan een ander taalgebied en waar de wet het gebruik van een andere taal dan die van het gebied waarin zij gelegen zijn, voorschrijft of toelaat, lijkt alvast geen rechtvaardiging voor de schending van die beginselen.

In het voorontwerp wordt voorts verduidelijkt dat de bestuurlijke lus niet kan worden toegepast in het cassatieberoep. Bij uitspraak nr. o9/4874 WW en og/4875 $\mathrm{WW}^{\mathrm{rog}}$ van 6 april $20 \mathrm{2} 2$ heeft de Nederlandse Centrale Raad van Beroep evenwel geoordeeld dat, indien tegen een uitspraak cassatie mogelijk is, voor het toepassen van een zogenoemde bestuurlijke lus, ter finale beslechting van het geschil, geen plaats is. A contrario zou dus wel kunnen worden gebruikgemaakt van de bestuurlijke lus indien geen cassatie mogelijk is, maar in de procedure voor de Raad voor Vergunningsbetwistingen is toch voorzien in het gebruik van de bestuurlijke lus, hoewel cassatieberoep tegen diens uitspraken openstaat bij de Raad van State. Niettemin, de uitsluiting van de bestuurlijke lus ingeval van administratief cassatieberoep kan worden bijgetreden, aangezien dat beroep geen bestuurlijke maar een rechtsprekende beslissing tot voorwerp heeft. Als de bestuurlijke lus voor het betreffende type geschillen opportuun wordt geacht, past het de toepassing ervan door het administratieve feitengerecht mogelijk te maken. De beschreven uitspraak van de Centrale Raad van Beroep staat haaks op de eigenheid van de administratieve cassatie.

Ten slotte kan nog worden verwezen naar de toekomstige hervormingsbevoegdheid van de Raad van State. In het voorontwerp wordt niet enkel bepaald dat de bestuurlijke lus niet kan worden gebruikt ingeval van cassatieberoep, kort geding, schadeloosstellingen en in het kader van procedures op grond van een bijzondere wet, maar ook dat de bestuurlijke lus niet kan worden toegepast wanneer de Raad van State beschikt over een hervormingsbevoegdheid. In die zogenoemde geschillen met volle rechtsmacht beperkt de Raad van State zich niet tot nietigverklaring, maar kan hij een nieuwe beslissing nemen die in de plaats komt van de bestreden

Io8 Parl.St. Senaat 20II-I2, nr. I563/4, p. 29.

Iog LJN BW3336. 
beslissing. Het voorontwerp voorziet in de verruiming van die bevoegdheid tot de administratieve geldboeten. De Raad van State zal in een dergelijk geval een arrest kunnen wijzen dat een definitieve oplossing biedt met betrekking tot de aangevochten geldboete, met inbegrip van de bepaling van het bedrag van de boete.

Wanneer de Raad van State met volle rechtsmacht kan oordelen, wordt het gebruik van de bestuurlijke lus dus uitgesloten. Er kan hierbij worden verwezen naar twee tussenuitspraken van I4 maart 2012 van het Nederlandse College van Beroep voor het bedrijfsleven. ${ }^{\text {Io }}$ Hoewel het College overeenkomstig artikel 8:72a Awb zelf in de zaak mocht voorzien, werd toch gekozen voor de bestuurlijke lus 'in het belang van de spoedige beëindiging van het geschil'. Sanders werpt op dat vanuit het perspectief van het beginsel ne bis in idem de bestuurlijke lus niet samengaat met de bestuurlijke boete, omdat het bestuursorgaan opnieuw de mogelijkheid wordt geboden om te vervolgen en de burger langer in onzekerheid blijft. ${ }^{\text {III }}$

Hoewel toepassing van de bestuurlijke lus zeker vaker overbodig kan zijn in gevallen waar de Raad van State over volle rechtsmacht (in internrechtelijke zin) beschikt, mag het nut van die toepassing toch niet op algemene wijze worden uitgesloten. Het argument ontleend aan het beginsel ne bis in idem kan zelfs als merkwaardig worden beschouwd: het aannemen zou betekenen dat de nietigverklaring van bestuurlijke sancties (vooralsnog met inbegrip van bestuurlijke geldboeten) door de Raad van State nooit zou kunnen worden gevolgd door een nieuwe sanctiebeslissing van het bestuur. Nochtans kan worden verdedigd dat het bestuur in een dergelijk geval in principe slechts een reeds ingestelde vervolging of zelfs enkel de beoordeling ervan herneemt wegens de nietigverklaring door een rechtsprekende instantie (zoals een strafgerecht in hoger beroep na cassatie), wat iets anders is dan uit eigen beweging een tweede keer overgaan tot (vervolging en) sanctie.

\subsection{Enkele gevallen waarin de bestuurlijke lus kan worden toegepast, maar ...}

Hierna worden bepaalde situaties kort besproken teneinde enkele voorbeelden te verschaffen van situaties waarin de bestuurlijke lus zou kunnen worden toegepast. Bortels stelt alvast vast dat het gebruik ervan door de Nederlandse Raad van State zich situeert ten aanzien van gebreken inzake zorgvuldige voorbereiding, belangenafweging en motivering. ${ }^{\mathrm{II} 2}$

IIo LJN BV9430 en LJN BV9426. Voor een ander voorbeeld, zie CBb 20 maart 20I2, LJN BW367I.

III T.N. Sanders, 'Het CBb als wetgever: de bestuurlijke lus toegepast bij de bestuurlijke boete' (noot onder CBb I4 maart 2012, LJN BV9430 en CBb I4 maart 2012, LJN BV9426), M\&M 2012, nr. 3, (I33) I37.

II2 H. Bortels, 'De bestuurlijke lus: aanzet naar een meer oplossingsgerichte bestuursrechter?', TBP 2013/5, (302), 308 . 
Wanneer een advies diende ${ }^{\mathrm{Ir} 3}$ te worden ingewonnen, maar dit werd over het hoofd gezien, kan toepassing worden gemaakt van de bestuurlijke lus. Het vereiste advies kan worden ingewonnen en indien het advies aansluit bij de bestreden beslissing, die vervolgens wordt gehandhaafd, ${ }^{\mathrm{II}} 4$ is er geen nood om tot nietigverklaring wegens miskenning van het vormvereiste van het advies over te gaan.

In het voorontwerp wordt bepaald dat het gebruik van de bestuurlijke lus er niet toe kan leiden dat na herstel het besluit een gewijzigde inhoud krijgt. De inhoud van het naderhand ingewonnen advies kan echter leiden tot een gewijzigde inhoud van de bestreden beslissing, zeker wanneer meerdere adviezen moeten worden gevraagd. Het advies kan zelfs een volledig nieuw licht op de zaak doen schijnen. Stel dat in de bestreden beslissing de aanvraag tot het bekomen van een wapenvergunning werd geweigerd omdat de verzoeker eigenaar zou zijn geweest van een wapen waarmee ooit een gewapende overval werd gepleegd. Uit het in het kader van de bestuurlijke lus ingewonnen advies van de procureur des konings blijkt echter dat uit onderzoek van het wapen volgt dat het uiteindelijk niet werd gebruikt in die gewapende overval. Indien de beslissing na het bekomen van het advies toch wordt gehandhaafd (maar dan op grond van andere redenen), zal de verzoeker middelen kunnen inroepen tegen de wijze waarop het gebrek werd hersteld en die zich dan ook zullen richten op het advies waarop de herstelbeslissing zich steunt. Dit bevestigt alvast dat de bestuurlijke lus wel tijdswinst oplevert voor het bestuur, maar geenszins voor de Raad van State. ${ }^{\mathrm{II}}$ In het jaarverslag $20 \mathrm{II}-\mathrm{I} 2^{\mathrm{II} 6}$ van de Raad voor Vergunningsbetwistingen is het volgende te lezen:

'Voorts wacht de Raad in het vierde werkjaar de grote uitdaging om de nieuwe procedureregeling te implementeren en toe te passen. De bestuurlijke lus en de bemiddeling zijn nieuwe rechtstechnieken die geleidelijk ingang zullen vinden. De vereenvoudigde behandeling zal de procedure in bepaalde gevallen gevoelig verkorten (...)'.

II3 Zie RvS 25 maart 20I3, nr. 222.969, Vervloet e.a.: 'Los van de vraag of dit voorafgaand advies [van de inspectie van Financiën] de inhoud en omvang zou hebben die de verzoekers in het middel eraan geven, is het inwinnen van dit voorafgaand advies een formaliteit die uitsluitend in het belang van het bestuur is gesteld. Het heeft daarom geen substantieel karakter. Particulieren kunnen zich bijgevolg tot staving van een beroep tot nietigverklaring, niet beroepen op het niet vervuld zijn van die formaliteit.'

II4 In die zin volstaat de eigen beslissingsbevoegdheid van het bestuur om het gebrek te herstellen. Het gegeven dat het eigenlijke herstel van het gebrek door een adviesorgaan van dat bestuur gebeurt, doet hieraan geen afbreuk.

II5 Zie tevens A. Collignon, 'De bestuurlijke lus in de praktijk', Bouwrecht 20Io, afl. 5, nr. 65, (395) 40I: 'De nu gepubliceerde tussenuitspraken laten wel zien dat met toepassing van de bestuurlijke lus de doorlooptijden bij de rechter kunnen oplopen. (...) Als daar de gegeven termijnen voor herstel en de daaropvolgende handelingen (zoals het indienen van een schriftelijke zienswijze door de overige partijen, en mogelijk een nieuwe zitting) bij worden opgeteld dan lijkt de bestuurlijke lus te leiden tot een vertraging voor het verkrijgen van een einduitspraak.'

P. 4 . 
Maar het is nog maar de vraag of de procedure gevoelig zal worden verkort met de bestuurlijke lus.

Het gebruik van de bestuurlijke lus bij gebrek aan een advies kan als problematisch worden ervaren, wat het volgende voorbeeld aantoont. In het arrest nr. 335.77I van 29 juni 2012 vernietigde de Franse Raad van State de beslissing van 26 november 2010 van de Franse minister van Cultuur en Communicatie om de film 'Antichrist' te censureren met een verbod voor minderjarigen die de leeftijd van zestien jaar niet hebben bereikt.

De Franse minister ontleende zijn bevoegdheid aan de Franse Code du cinéma et de l'image animée', dat in artikel L2II-I stelt dat een cinematografische voorstelling is onderworpen aan het visum voor exploitatie afgegeven door de minister van Cultuur. Voor zijn verbod om de film toegankelijk te maken voor minderjarigen onder de zestien jaar had de minister zich gebaseerd op het advies van 28 mei 2009 van de classificatiecommissie, waarvan artikel 2 van het decreet nr. 90-I74 van 23 februari 1990 'pris pour l'application des articles ig à 22 du code de l'industrie cinématographique et relatif à la classification des oeuvres cinématographiques' bepaalt dat het gemotiveerd moet zijn en door de bevoegde minister openbaar kan worden gemaakt. Het eerste exploitatievisum werd door de Franse Raad van State op 25 november 2009 vernietigd wegens geen afdoende motivering. Het advies van de classificatiecommissie, waarop de minister zich had gebaseerd, stelde namelijk dat de film zich situeerde in een klimaat van geweld zonder te verduidelijken waarom dit geweld het voorgestelde verbod rechtvaardigde, waardoor het afbreuk deed aan de verplichte motivering van artikel 2 van het decreet nr. 90-I74. De minister verleende een tweede exploitatievisum zonder evenwel een nieuw advies te vragen aan de classificatiecommissie. De Franse Raad van State oordeelde in het arrest nr. 335.77I als volgt:

‘Considérant d'autre part, que cette irrégularité prive le ministre d'un élément essentiel pour déterminer, dans l'exercice du pouvoir de délivrer les visas d'exploitation des œuvres cinématographiques qu'il tient des dispositions précitées de l'article L. 211-1 du code du cinéma et de l'image animée, le choix qui lui incombe entre les différentes restrictions qu'il peut éventuellement imposer à la diffusion de l'œuvre, au regard des nécessités de la protection de l'enfance et de la jeunesse, du respect de la dignité humaine et de la liberté d'expression, la motivation de l'avis de la commission devant lui permettre, compte tenu de la pluralité de sa composition reflétant les différents intérêts en cause, d'apprécier les modalités de conciliation entre ces nécessités; que l'absence de motivation est également susceptible de priver le public d'un élément d'information sur les circonstances qu'il a prises en considération pour délivrer le visa si, comme l'article 2 du décret du 23 février 1990 lui en donne la faculté, le ministre rend public l'avis de la commission; qu'ainsi, l'insuffisance de motivation de l'avis de la commission est susceptible d'exercer une influence sur la décision du ministre et de priver les différents intéressés d'une garantie au regard des limitations à la liberté d'expression que constitue toute mesure restreignant la diffusion d'une œuvre cinématographique; que les associations requérantes sont, par suite, fondées à demander l'annulation pour ce motif de la décision attaquée.' 
Een ander voorbeeld is het arrest nr. 353.288 van 26 december 2012 van de Franse Raad van State. ${ }^{117}$ In dat arrest ging het over het advies dat de Franse minister van Werk diende te vragen aan de vakbonden vooraleer een besluit inzake de herziening van de lijst van knelpuntberoepen kon worden genomen. De adviesaanvraag was evenwel zodanig opgesteld dat het leek dat een persoonlijk advies van de geadresseerde en niet van de vakbond zelf werd gevraagd en de aanvraag leek niet te zijn opgestuurd naar de verantwoordelijken van de vakbonden. Tevens werd geen andere vorm van consultatie georganiseerd. Dergelijke onregelmatigheid werd geacht een invloed te hebben kunnen gehad op de inhoud van de beslissing.

Enige omzichtigheid bij het gebruik van de bestuurlijke lus wegens het niet hebben gevraagd van een advies is dan ook vereist, indien rekening zou worden gehouden met het vereiste dat het vormgebrek invloed heeft kunnen hebben op de inhoud van de beslissing of dat het de belanghebbenden een waarborg heeft ontnomen. De Raad van State zou dan geval per geval moeten bekijken, ${ }^{\mathrm{II}}$ gesteund op het administratief dossier, of aan voormelde voorwaarde is voldaan, waarna kan worden overwogen om de bestuurlijke lus te gebruiken. In een dergelijk geval zou de Raad van State de bestuurlijke lus slechts voorstellen, indien hij, gelet op de omstandigheden van de zaak, oordeelt dat in de zaak naar alle waarschijnlijkheid geen andere beslissing kan worden genomen! Het is wel niet evident dat de Raad van State vooraf zou moeten inschatten (of speculeren over) wat de inhoud van een advies zal zijn.

Tevens lijkt de bestuurlijke lus niet mogelijk in gevallen waarin het advies danig de contouren bepaalt van de uiteindelijke beslissing die kadert in een ruime discretionaire bevoegdheid, zoals dit bijvoorbeeld volgt uit het arrest nr. 222.969 van 25 maart 2013 van de Belgische Raad van State. Zo heeft de wetgever het instellen van een of ander systeem vermeld in artikel $36 / 24^{119}$ van de wet van 22 februari 1998 tot vaststelling van het organiek statuut van de Nationale Bank van België ${ }^{120}$ afhankelijk gemaakt van het inwinnen van het advies van de Nationale Bank. De Koning kan dan ook slechts voorzien in een systeem van toekenning van staatswaarborg voor de terugbetaling aan vennoten die natuurlijke personen zijn van hun deel in het

II7 Zie de bespreking van K. Geneviève, 'De l'influence du vice dans la procédure administrative...', te vinden op <http://koubi.fr./spip.php?article728> (laatst geconsulteerd op 6 juli 20I3).

iı Zie ook A. Gossement, 'Vice de procédure: vers la fin du juridisme procédurier?', te vinden op $<$ www.arnaudgossement.com/archive/2012/02/I4/vice-de-procedure-vers-la-fin-du-juridisme. html $>$ (laatst geconsulteerd op 6 juli 20I3).

II9 'S I. De Koning kan, na advies van de Bank, ingeval zich een plotse crisis voordoet op de financiële markten of in geval van een ernstige dreiging van een systemische crisis, teneinde de omvang of de gevolgen hiervan te beperken: (...)

$3^{\circ}$ in een systeem voorzien, in voorkomend geval door middel van reglementen vastgesteld overeenkomstig $\mathrm{I}^{\circ}$, van toekenning van de staatswaarborg voor de terugbetaling aan vennoten die natuurlijke personen zijn van hun deel in het kapitaal van coöperatieve vennootschappen, erkend overeenkomstig het koninklijk besluit van 8 januari ig 62 tot vaststelling van de voorwaarden tot erkenning van de nationale groeperingen van coöperatieve vennootschappen en van de coöperatieve vennootschappen, die instellingen zijn onderworpen aan toezicht krachtens voornoemde wetten of waarvan minstens de helft van het vermogen is geïnvesteerd in dergelijke instellingen; (...)'.

I20 BS 29 maart 1998. Deze wet werd meermaals gewijzigd. 
kapitaal van coöperatieve vennootschappen, ingeval zich een plotse crisis voordoet op de financiële markten of in geval van een ernstige dreiging van een systeemcrisis en nadat de Nationale Bank om advies werd gevraagd, waarmee de wetgever 'onmiskenbaar aangegeven heeft dat de Nationale Bank van België het geëigende orgaan is om uit te maken of de wettelijke voorwaarden vervuld zijn om de geplande maatregel te institutionaliseren'. ${ }^{121}$ In dergelijke omstandigheid lijkt er geen mogelijkheid te bestaan om de bestuurlijke lus aan te wenden, indien de Koning zou zijn opgetreden zonder het advies te hebben gevraagd ${ }^{122}$ van de Nationale Bank wegens het belang van dat advies in de ruime discretionaire besluitvorming. Voormelde stelling lijkt daarenboven als gevolg te hebben dat het overslaan van een advies, terwijl de beslissing slechts kan worden genomen 'op eensluidend advies', de toepassing van de bestuurlijke lus in de weg staat. ${ }^{123}$

Wat met de schending van een adviesverplichting die de openbare orde raakt? ${ }^{124}$ Een middel dat is gebaseerd op de miskenning van de adviesverplichting van de Afdeling Wetgeving van de Raad van State, zoals verwoord in artikel 3 RvS-wet, raakt volgens de vaste rechtspraak van de Raad van State de openbare orde. ${ }^{125}$ Doordat de raadpleging van de Afdeling Wetgeving in de gevallen waarin deze verplicht is, een substantieel procedurevoorschrift is dat de openbare orde raakt, kan de schending zelfs ambtshalve worden aangevoerd. ${ }^{\mathrm{I} 2}$ Er zou kunnen worden geargumenteerd dat bij niet-raadpleging van de Afdeling Wetgeving kan worden gebruikgemaakt van de bestuurlijke lus indien een beroep tot nietigverklaring met betrekking tot het besluit, waarvan het ontwerp niet was voorgelegd aan de Afdeling Wetgeving, hangende is voor de Afdeling Bestuursrechtspaak. Het bestuur zou hierbij de mogelijkheid krijgen om het ontwerp alsnog aan de Afdeling Wetgeving voor te leggen, waarna het bestuur, eenmaal het advies van de Afdeling Wetgeving ontvangen, kan beslissen of de in het geding toepasselijke bepalingen worden behouden. Beslist het bestuur dat die worden behouden, dan kan de Afdeling Bestuursrechtspraak niet meer overgaan tot vernietiging op de grond dat aan de adviesverplichting van de Afdeling Wetgeving niet werd voldaan; beslist het bestuur dat die niet worden behouden, dan kan de Afdeling Bestuursrechtspraak, alvast minstens voor de rechtszekerheid, die bepalingen vernietigen. Het voorgaande houdt alvast in dat niet per se tot vernietiging zou moeten worden overgegaan indien het advies van de Afdeling Wetgeving inzake een reglementair besluit niet werd ingewonnen. Indien

I2I RvS 25 maart 20I3, nr. 222.969, Vervloet e.a.

I22 Ter herinnering: de commissie-Berx adviseerde dat een procedure- en vormfout als irrelevant dient te worden beschouwd als een noodzakelijk advies naderhand werd ingewonnen.

I23 Zie ook C. Broyelle, 'L'impact du vice de procédure sur la légalité de l'acte administratif', La Semaine Juridique Administrations et Collectivités territoriales 2 april 20I2, 2089, § 2 (geconsulteerd via $<$ www.lexisnexis.com $>$ ).

I24 Een vraag gesteld in 'Intervention de David Renders et de Benoit Gors' in Publicum juni $2013,29$.

I25 Zie o.m. A. Wirtgen, Raad van State I. afdeling administratie. 3. Middelen en het ambtshalve aanvoeren van middelen in het bijzonder in Administratieve rechtsbibliotheek, Brugge: Die Keure 2004, p. III-II2. Als voorbeelden kunnen worden aangehaald: RvS 23 maart 2009, nr. I9I.732, Verschuere en RvS I5 februari 20I2, nr. 218.000, Verhelst e.a.

I26 Zie bijvoorbeeld RvS 9 november 2009, nr. I97.657, vzw Verbond der Verzorgingsinstellingen. 
na het onderzoek door de Afdeling Wetgeving wordt vastgesteld dat geen bijzondere opmerkingen moeten worden gemaakt aangaande de in het annulatieberoep toepasselijke bepalingen, is de eerdere vernietiging op grond van de schending van de adviesverplichting op zijn minst wel jammer te noemen, zeker wanneer alle middelen in het verzoekschrift, die geen betrekking hebben op de miskenning van de adviesverplichting, door de auditeur reeds ongegrond werden bevonden.

Het is echter niet aangewezen dat de Afdeling Wetgeving zou tussenkomen in een geschil dat hangende is voor de Afdeling Bestuursrechtspraak, op gevaar van beïnvloeding van de uitkomst van dat geschil door eerstgenoemde, waardoor ook hier de toepassing van de bestuurlijke lus lijkt uitgesloten.

\section{Onbevoegdheid van de steller van de handeling en handtekeningsbevoegdheid}

Bij arrest nr. I70.I76 van I9 april 2007 vernietigde de Raad van State artikel 27 van het ministerieel besluit van 3 januari 2002 tot vaststelling van de criteria voor de erkenning van geneesheren-specialisten in de psychiatrie, ${ }^{127}$ in de mate dat dit artikel 27 er niet in voorzag dat de bepalingen met betrekking tot de neuropsychiatrie in het ministerieel besluit van 29 juli $1987^{128}$ niet werden opgeheven. Artikel 35 ter van het koninklijk besluit nr. $78^{129}$ bepaalde dat de Koning de lijst vaststelt van de bijzondere beroepstitels en van de bijzondere beroepsbekwaamheden van de beoefenaars van gezondheidszorgberoepen, terwijl het bestreden artikel 27 van het ministerieel besluit van 3 januari 2002 er in wezen toe strekte dat de bijzondere beroepstitel van geneesheer-specialist in de neuropsychiatrie eigenlijk inhoudsloos werd en de facto leek te worden afgeschaft. De Raad van State oordeelde dan ook dat een dergelijke bevoegdheid alleen aan de Koning toekwam. Hoewel Renders en Gors de mening zijn toegedaan dat een gebrek wegens onbevoegdheid niet kan worden geregulariseerd, lijkt het toch mogelijk dat met toepassing van de bestuurlijke lus de Koning in een dergelijk geval de tijd zou krijgen om de inhoud van het ministerieel besluit op te nemen in een koninklijk besluit. Hierbij kan worden opgemerkt dat in de voorbereidende werkzaamheden van de Nederlandse Tweede Kamer drie categorieën bevoegdheidsgebreken werden geïdentificeerd: (I) het besluit is genomen namens een op zichzelf bevoegd bestuursorgaan, maar zonder toereikende grondslag, omdat een mandaatbesluit ontbreekt of onverbindend is (bijvoorbeeld een afdelingshoofd namens de minister), (2) het besluit is genomen door een onbevoegd bestuursorgaan, maar het bevoegde bestuursorgaan is een onderdeel van dezelfde rechtspersoon (bijvoorbeeld het college van burgemeester en schepenen in plaats van de burgemeester), en (3) het besluit is genomen door een onbevoegd bestuursorgaan, maar het bevoegde bestuursorgaan is een onderdeel van een andere rechtspersoon (bijvoorbeeld het college van burgemeester en schepenen in plaats van de deputatie). Terwijl de bestuurlijke lus mogelijk wordt geacht in de eerste en tweede

I27 BS 2I februari 2002.

I28 BS I2 augustus I987, erratum BS 20 oktober 1987.

I29 BS I4 november I967, erratum BS I2 juni I968. 
categorie, lijkt dit niet het geval te zijn voor de derde categorie omdat het meer voor de hand zou liggen om dan zelf in de zaak te voorzien, ${ }^{\mathrm{I} 30}$ wat evenwel een bevoegdheid is waarover de Belgische Raad van State niet beschikt, waardoor in België voor de drie categorieën de bestuurlijke lus zou kunnen worden toegepast.

Een ander voorbeeld is het arrest nr. I67.22I van 29 januari 2007. Op 2 juni 2004 diende de bewakingsonderneming bvba B.S.M. een aanvraag in tot het verkrijgen van een identificatiekaart voor het uitoefenen van een uitvoerende functie in een bewakingsonderneming. De vergunning werd geweigerd met een 25 augustus 2006 gedateerde beslissing, ondertekend door L.H., kabinetschef, 'i.o.' Patrick Dewael, minister. In het auditoraatsverslag werd ambtshalve de onbevoegdheid van de steller van de bestreden handeling opgeworpen. De leden van een ministerieel kabinet zijn namelijk persoonlijke medewerkers van de minister, geen administratieve overheid. Ambtshalve stelde de Raad van State dan ook vast dat de kabinetschef niet bevoegd was om in de plaats van de minister van Binnenlandse Zaken aan de verzoeker de gevraagde vergunning te weigeren, waardoor het annulatieberoep gegrond was. Met de bestuurlijke lus had aan de minister van Binnenlandse Zaken de mogelijkheid kunnen worden geboden om de beslissing tot weigering van de gevraagde vergunning als bevoegde overheid te ondertekenen. Indien de minister die beslissing ondertekent, dan is het vormgebrek hersteld. Er moet natuurlijk wel rekening worden gehouden met de andere middelen die in het initieel verzoekschrift werden opgeworpen, want slechts als er op geen andere grond tot nietigverklaring dient te worden overgegaan, kan de bestuurlijke lus worden toegepast.

De Nederlandse Raad van State heeft bij uitspraak nr. 200904380/I/TI/MI ${ }^{13 \mathrm{I}}$ van I7 maart 2010 in een soortgelijke aangelegenheid reeds toepassing gemaakt van de bestuurlijke lus. Zo had bij besluit van II november 2008 het college van Gedeputeerde Staten van Fryslân aan de verzoeker een drietal lasten onder dwangsom opgelegd met betrekking tot een scheepswerf. Nadat het beroep bij besluit van 24 april 2009 door het college werd verworpen, makkte de verzoeker de zaak aanhangig bij de Nederlandse Raad van State, waar werd betoogd dat voormeld besluit ten onrechte niet door de commissaris van de Koningin was ondertekend en niet door de secretaris was meeondertekend. De Nederlandse Raad van State oordeelde dat de medeondertekening door de secretaris was vereist en dat het besluit in strijd met artikel 59a lid van de Provinciewet was genomen. De Raad van State droeg het college van Gedeputeerde Staten van Fryslân op om binnen twee weken na de verzending van de uitspraak (I) het besluit van 24 april 2009 in overeenstemming te brengen met het bepaalde in artikel 59a lid 3 van de Provinciewet dan wel daarvoor in de plaats een ander besluit te nemen, en (2) het herstelde dan wel het vervangende besluit aan de Raad van State toe te zenden.

I30 Kamerstukken II 2008/o9, 3I 352, nr. 8, p. 23-24.

I3I LJN BL7777. Dit arrest werd reeds aangehaald in voetnoot 59. 
Als voorbeeld kan het arrest nr. 2II.703 van 2 maart 20II, gewezen op andersluidend advies van het auditoriaat, worden aangehaald. Die zaak had betrekking op een gedetineerde die door de gevangenisdirecteur van Wortel, afdeling Tilburg (Nederland) de tuchtsanctie kreeg opgelegd van één maand individueel regime, drie maanden geen bezoek van mevrouw H.D.H. en drie maanden geen glasbezoek. De gedetineerde zou tijdens het bezoek drugs hebben overgedragen vanaf de bezoekster, mevrouw H.D.H., naar zichzelf, wat werd geconstateerd door het personeel en wat tevens werd geregistreerd door een camera. In het hoorverslag van de tuchtzitting vroeg de gedetineerde of er beelden waren opgenomen en dat hij die beelden wenste te zien. De gevangenisdirecteur legde de voormelde tuchtsanctie op op grond van de bevestiging van het gevangenispersoneel dat de overdracht had gezien, wat tevens werd bevestigd door de camerabeelden. Volgens de Raad van State bleek uit het rapport aan de directeur, waarop de gevangenisdirecteur zich baseerde om aan de gedetineerde de tuchtsanctie op te leggen, echter dat de steller van dit rapport 'dacht' 'een overdracht te hebben gezien' en dat hij zijn 'collega [wilde] vragen om bevestiging vanuit de camerabeelden' en, nadat hij die collega, blijkens het tuchtrapport, eerder had gevraagd 'om de camera eens op de tafel te richten voor extra toezicht'. De Raad van State overwoog vervolgens dat uit het rapport aan de directeur bleek dat de steller ervan niet geheel zeker was een overdracht van drugs aan de gedetineerde te hebben waargenomen. De camerabeelden maakten dan ook een determinerend bewijs uit voor de overdracht van contrabanden, waardoor de 'rechten van verdediging van de verzoeker zijn geschonden doordat hem, niettegenstaande zijn uitdrukkelijke vraag daartoe, geweigerd werd de kwestieuze camerabeelden te bekijken en daarover tegenspraak te voeren, terwijl deze van essentieel belang konden zijn voor de beoordeling van de tenlastelegging en de geloofwaardigheid van verzoekers verweer.'

In een dergelijke situatie zou de Raad van State bij tussenarrest kunnen opleggen dat de gedetineerde de mogelijkheid zou moeten krijgen om binnen een bepaalde termijn verweer te voeren, waarna de gevangenisdirecteur kan beslissen om al dan niet de tuchtsanctie te bevestigen. Interessant om hierbij te melden is dat het auditoraat het tweede middel, waarin onder meer werd ingeroepen dat de tuchtsanctie niet in verhouding stond met de vermoedelijke inbreuk die de gedetineerde zou hebben gepleegd en dat het in verhouding staan met de opgelegde sanctie niet voldoende was gemotiveerd, ongegrond had bevonden. Hoewel het niet vooraf is geweten welk verweer al dan niet zal kunnen worden afgeleid uit het bekijken van de camerabeelden, lijkt de verplichting om, in toepassing van de bestuurlijke lus, de gedetineerde alsnog te horen, in een dergelijke omstandigheid dan ook niet meer in te houden dan een verplicht nummertje. 


\subsection{Motivering}

De motivering, die 'één van de belangrijkste vormen is', ${ }^{132}$ is nog steeds een heikel punt in bestuursbeslissingen. Laten wij een voorbeeld nemen dat betrekking heeft op de tewerkstelling van buitenlandse werknemers. Artikel I § I van het koninklijk besluit van 7 oktober 2009 houdende bijzondere bepalingen met betrekking tot de tewerkstelling van sommige categorieën van buitenlandse werknemers ${ }^{\mathrm{I} 33}$ bepaalt dat in toepassing van artikel 4 § 2 lid 2 van de wet van 30 april 1999 betreffende de tewerkstelling van buitenlandse werknemers ${ }^{\mathrm{I} 34}$ een arbeidsvergunning kan worden toegekend wanneer de werkgever bepaalde documenten voorlegt, waaronder 'een of meerdere arbeidsovereenkomsten, opgesteld volgens het model als bijlage gevoegd bij dit besluit, met de buitenlandse onderdaan bedoeld in $\mathrm{I}^{\circ}$, hetzij voor bepaalde tijd van minstens één jaar, hetzij voor onbepaalde tijd.' Als bijlage bij het koninklijk besluit wordt een model van arbeidsovereenkomst opgenomen, met als titel 'Vermeldingen en bepalingen die in de arbeidsovereenkomst van de buitenlandse werknemer moeten voorkomen'. Stel dat uit het administratief dossier blijkt dat de werkgever de aanvraag niet heeft ingediend op basis van een arbeidsovereenkomst voor het tewerkstellen van een buitenlandse onderdaan, maar op basis van een gewone arbeidsovereenkomst, het gevolg is dan dat het bestuur de aanvraag weigert. In het arrest nr. 220.018 van 28 juni 2012 heeft de Raad van State, op andersluidend advies van het auditoraat, hier aangaande geoordeeld dat uit het loutere gegeven dat in het aanvraagdossier niet het modelformulier voorkomt dat specifiek is bestemd voor een aanvraag overeenkomstig het koninklijk besluit van 7 oktober 2009 niet kan worden afgeleid dat de aanvraag onvolledige of onjuiste gegevens bevat. In de beslissing werden bovendien geen concrete gegevens vermeld die door het niet gebruiken van het geëigende formulier zouden ontbreken of onvolledig of onjuist zouden zijn. Door aldus de aanvraag te weigeren zonder de vermelding van deugdelijke motieven waarop die weigeringsbeslissing was gesteund, werd de motiveringsplicht miskend. Met de bestuurlijke lus had de Raad van State dan ook het Vlaamse Gewest de mogelijkheid kunnen geven om binnen een bepaalde termijn mee te delen welke in de bijlage bij het koninklijk besluit van 7 oktober 2009 voorgeschreven vermeldingen of gegevens ontbraken in de aanvraag.

\section{$5 \quad$ Procedures in kort geding}

In het voorontwerp wordt uitdrukkelijk opgenomen dat de bestuurlijke lus slechts kan worden toegepast in een geding ten gronde, omdat er in het kort geding nog geen definitief standpunt is ingenomen over de middelen. Hoewel het klopt dat in een kortgedingprocedure nog geen definitief standpunt over de middelen is

I32 A. Mast, J. Dujardin, M. Van Damme en J. Vande Lanotte, Overzicht van het Belgisch administratief recht, Mechelen: Kluwer 2006, p. 996.

I33 BS I4 oktober 2009.

I34 BS 2I mei I999. Deze wet werd gewijzigd bij koninklijk besluit van 20 juli 2000 (BS 30 augustus 2000), wet van 6 juni 2010 (BS I juli 20I0) en wet van II februari 2013 (BS 22 augustus 2013). 
ingenomen, dient deze stelling toch met enige realiteitszin te worden bekeken. 'De kans dat de Raad van State de middelen in het kader van een vernietigingsberoep anders zou beoordelen lijkt in de meeste gevallen inderdaad eerder illusoir. ${ }^{\mathrm{I}_{35}}$

\section{I Gewone schorsing}

In Nederland kan de bestuurlijke lus wel worden aangewend in de kortgedingprocedure. Vooreerst kan worden verwezen naar het arrest nr. 20I0I0202/2/R en $201010202 / \mathrm{I} / \mathrm{TI} / \mathrm{R}_{3}{ }^{\mathrm{I} 36}$ van 28 april 20II, gewezen door de Nederlandse Raad van State, waarin werd gebruikgemaakt van de bestuurlijke lus in een voorlopigevoorzieningprocedure. Daarenboven voorziet artikel 4.8.4 § I lid I VCRO dat de Raad voor Vergunningsbetwistingen 'in elke stand van het geding' van de bestuurlijke lus kan gebruikmaken. In het allereerste ${ }^{137}$ arrest van de Raad voor Vergunningsbetwistingen, waarin om de toepassing van de bestuurlijke lus werd verzocht, werd evenwel geoordeeld dat deze toepassing 'in de huidige stand van het geding', meer bepaald de schorsingsprocedure, 'niet wenselijk' was. ${ }^{\mathrm{I}{ }^{8}}$ Bovendien lijkt het er op dat de Raad voor Vergunningsbetwistingen niet geneigd is de bestuurlijke lus toe te passen in een kortgedingprocedure.

Toch bepaalt het voorontwerp dat een koninklijk besluit als het ware kan voorzien in een combinatie kort geding/procedure ten gronde, teneinde de bestuurlijke lus te gebruiken. De hybride situatie van het kort geding en het beroep ten gronde samen is een procedure die de Raad van State reeds bekend is. Het auditoraat kan er namelijk voor opteren om niet enkel de vordering tot schorsing te behandelen, maar onmiddellijk via de kortedebattenprocedure (artikel 93 lid I van het algemeen procedurereglement) ${ }^{139}$ het beroep ten gronde af te werken. Indien evenwel het audi-

I35 D. D’Hooghe en N. Kiekens, 'Tenuitvoerlegging van arresten van de Raad van State inzake overheidsopdrachten', in: I. Cooreman, D. Lindemans en L. Peeters (red.), De tenuitvoerlegging van arresten van de Raad van State. Administratieve Rechtsbibliotheek, Brugge: Die Keure 2012, (405) 432, randnr. 4I.

I36 LJN BQ34II.

I37 Er is ook nog een tweede arrest van de Raad voor Vergunningsbetwistingen waarin de tussenkomende partij het gebruik van de bestuurlijke lus heeft voorgesteld, zijnde het arrest nr. A/2013/032I van II juni 2013, maar het beroep diende nog te worden behandeld volgens de oude procedure die de bestuurlijke lus niet toeliet ('Op het verzoek van de tussenkomende partij tot het toepassen van de "bestuurlijke lus" kan niet worden ingegaan. Artikel 4.8.4 VCRO, zoals gewijzigd bij decreet van 6 juli 2012 houdende wijziging van diverse bepalingen van de Vlaamse Codex Ruimtelijke Ordening, wat de Raad voor Vergunningbetwistingen betreft, kan overeenkomstig artikel 8 van dit decreet enkel toegepast worden op beroepen die zijn ingediend na de inwerkingtreding ervan. De inwerkingtreding werd bij besluit van de Vlaamse regering van I3 juli 2012 vastgesteld op I september 20I2.').

I3 8 Raad voor Vergunningsbetwistingen I9 maart 2013, nr. S/2013/0045.

I39 Art. 93 van het algemeen procedurereglement: 'Indien blijkt dat het beroep tot nietigverklaring doelloos is of dat het slechts korte debatten vereist, brengt de auditeur daarvan onverwijld verslag uit aan de voorzitter van de kamer belast met de zaak. De voorzitter roept de verzoekende partij, de verwerende partij en de tussenkomende partij op om op korte termijn voor hem te verschijnen; het verslag wordt bij de oproeping gevoegd. Indien de voorzitter het eens is met de conclusies van het verslag, wordt de zaak definitief beslecht. Indien hij van oordeel is dat de zaak niet in zoverre gereed is dat zij definitief kan worden beslecht, verwijst hij deze naar de gewone 
toraat van oordeel is dat de bestuurlijke lus kan worden toegepast, dan zal geen beroep kunnen worden gedaan op artikel 93 lid I van het algemeen procedurereglement, maar zal een andere procedure voorhanden zijn. In de gevallen waarin het auditoraat vaststelt dat, terwijl de spoedeisendheid vaststaat, er grond kan bestaan voor de toepassing van de bestuurlijke lus en zo de nietigverklaring te vermijden valt, kan, voor zover het bestuur te kennen geeft die toepassing te aanvaarden en de Raad van State de gemaakte analyse van het geschil deelt, de zaak worden overgeheveld naar de procedure van het beroep tot nietigverklaring, terwijl de bestreden handeling intussen wordt geschorst. Aanvaardt het bestuur de toepassing van de bestuurlijke lus niet of beslist de kamer die niet toe te passen, dan zou zij rechtstreeks kunnen beslissen over het beroep tot nietigverklaring. Het is wel van belang dat het toekomt aan de auditeur om te oordelen of hij - met inachtneming van het recht van verzoekende partij op een spoedige behandeling van de schorsingsprocedure - de mogelijkheid heeft om alle middelen in de schorsingsprocedure te onderzoeken teneinde het gebruik van de bestuurlijke lus te kunnen voorstellen. Het lijkt praktisch onmogelijk dat de staatsraad op eigen initiatief de bestuurlijke lus inzet wegens de aard van de schorsingsprocedure, behoudens de situatie waarin het voor de auditeur mogelijk is gebleken om toch alle middelen te onderzoeken.

\subsection{UDN}

De bestuurlijke lus in de procedure bij uiterst dringende noodzakelijkheid, waarin het auditoraat geen verslag opstelt, maar enkel een advies ter terechtzitting geeft, wordt door het voorontwerp niet toegelaten. Er zijn inderdaad bedenkingen te maken bij het gebruik van de bestuurlijke lus in die procedure, zeker omdat van het auditoraat niet kan worden verwacht dat het in een procedure bij uiterst dringende noodzakelijkheid alle middelen, incluis de excepties inzake rechtsmacht en ontvankelijkheid, onderzoekt teneinde te zien of reeds in die procedure al dan niet een bestuurlijke lus kan worden gebruikt.

Het is hier evenwel gepast om te verwijzen naar de praktijk van het overheidsopdrachtencontentieux, waarin nu reeds zoveel mogelijk wordt vermeden om de schorsing van de tenuitvoerlegging bij uiterst dringende noodzakelijkheid te bevelen wegens het niet voldoen aan een vormvereiste zoals de formele motivering. In een dergelijke procedure wordt namelijk rekening gehouden 'met de omstandigheden van de zaak'. Dit vloeit ook voort uit artikel 65/15 lid 3 van de wet van 24 december I993 betreffende de overheidsopdrachten en sommige opdrachten voor aanneming van werken, leveringen en diensten dat luidt als volgt:

'De verhaalinstantie houdt rekening met de vermoedelijke gevolgen van de schorsing van de uitvoering en van de voorlopige maatregelen voor alle belangen die kunnen worden geschaad, alsook met het openbaar belang, en kan beslissen om de schorsing van de uitvoering of de voorlopige

rechtspleging.' Het komt enkel het auditoraat toe te beslissen of al dan niet wordt gebruikgemaakt van art. 93 van het algemeen procedurereglement. 
maatregelen niet toe te staan wanneer hun negatieve gevolgen groter zouden zijn dan hun voordelen. ${ }^{140}$

Het voorontwerp voorziet in de mogelijkheid om de afweging van belangen uit te breiden tot alle bestuurshandelingen.

\section{Bestuurlijke lus: enkel ten bate van het bestuur}

Laten wij aannemen dat een inschrijver voor het bekomen van een overheidsopdracht onregelmatig wordt verklaard wegens een vormgebrek in de vereiste handtekening. De vereiste ondertekening van de offerte is een substantiële formaliteit, waarvan de niet-naleving de nietigheid van de offerte wegens substantiële onregelmatigheid tot gevolg heeft. Het gebrek aan ondertekening kan niet worden gedekt nu zulks onzekerheid met zich kan brengen betreffende de verbintenissen van de inschrijvers die onder meer de uitvoering van de werken overeenkomstig de bepalingen van het bestek omvatten. ${ }^{\mathrm{I}{ }^{\mathrm{I}} \mathrm{I}}$ Indien een offerte substantieel onregelmatig is, moet het bestuur die offerte buiten beschouwing laten; ter zake beschikt het bestuur niet over een discretionaire bevoegdheid. ${ }^{\mathrm{I} 42}$ Onder vereiste ondertekening wordt ook begrepen de rechtsgeldige ondertekening, zijnde de ondertekening in overeenstemming met de statuten van de inschrijver. Stel dat uit het administratief dossier blijkt dat de offerte van de geweerde inschrijver werd ondertekend door medewerkers die verantwoordelijk zijn voor de behandeling van de dossiers inzake overheidsopdrachten, maar die evenwel geen bestuurders zijn van de inschrijver, terwijl de ondertekeningsbevoegdheid toekomt aan de bestuurders. Voor de Raad van State verzoekt de tweede gerangschikte in de gunningsprocedure om de schorsing bij uiterst dringende noodzakelijkheid en de nietigverklaring van de beslissing om te gunnen aan de inschrijver waarvan de offerte niet werd ondertekend door een bestuurder. Gedurende de procedure voor de Raad van State verklaart de geweerde inschrijver dat het gaat om een materiële vergissing en dat een bestuurder ondertussen aan de

I40 Een voorbeeld: in het arrest nr. I88.958 van I8 december 2008 werd de vordering tot schorsing bij uiterst dringende noodzakelijkheid verworpen op basis van een belangenafweging. Die zaak had betrekking op een overheidsopdracht voor de levering van vaccins voor de Vlaamse bevolking vanaf 2009. In het advies ter terechtzitting stelde het auditoraat vast dat de verzoeker belang had bij zijn vordering en dat aan de voorwaarden van artikel I7 § I en 2 RvS-wet was voldaan (zijnde het voorhanden zijn van uiterst dringende noodzakelijkheid, het aanvoeren van ernstige middelen die de nietigverklaring van de aangevochten beslissing kunnen verantwoorden, en de onmiddellijke tenuitvoerlegging van de bestreden beslissing kan een moeilijk te herstellen ernstig nadeel berokkenen). Toch concludeerde het auditoraat in zijn advies dat dit niet tot de gevraagde schorsing mocht leiden, aangezien het nadeel van de verzoeker niet opwoog tegen het risico dat de continuïteit van vaccinatieprogramma's in het gedrang zou komen. De Raad van State oordeelde dan ook dat het private nadeel dat de verzoeker kan ondergaan, doordat zij de kans verloor de opdracht uit te voeren, moest wijken voor de dreiging dat bij schorsing de vaccinatieprogramma's worden onderbroken wat het algemeen belang van de volksgezondheid zou bedreigen. De wet van 24 december 1953 is opgeheven op I juli 2013, maar ook art. I5 van de nieuwe wet van 17 juni 2013 voorziet in een afweging van belangen.

I4I RvS I december 20I0, nr. 209.38I, Borchers Kreislaufwirtschaft GMBH.

I42 RvS 6 april 2006, nr. I57.4I8, nv CH Cleaning Services. 
aanbestedende instantie een volgens de statuten rechtsgeldig ondertekende offerte heeft overgemaakt. Daarenboven laat de aanbestedende instantie aan de Raad van State weten geen bezwaar te hebben tegen het feit dat voormelde inschrijver alsnog regelmatig wordt verklaard, omdat hij de goedkoopste offerte had ingediend, waardoor er alvast een algemeen (budgettair) belang is om toch nog die inschrijver te kiezen. ${ }^{143}$

Een andere situatie die kan worden aangehaald, is die van de aanvraag tot het bekomen van een wapenvergunning. Artikel II $\$ 3,9^{\circ}$, van de wet van 8 juni 2006 houdende regeling van economische en individuele activiteiten met wapens bepaalt dat een wapenvergunning slechts wordt verleend indien de aanvrager een wettige reden voor de verwerving en het voorhanden hebben van het betrokken wapen en de munitie opgeeft. Stel dat de aanvrager vergeet om een wettige reden op te geven, dan is de gouverneur, en in beroep de minister van Justitie, verplicht de aanvraag af te wijzen. Zelfs in geval van vernietiging van de beslissing tot weigering van afgifte van de wapenvergunning zou de door de verzoekende partij gevraagde vergunning opnieuw moeten worden geweigerd, ${ }^{144}$ waardoor de Raad van State niet anders kan dan vaststellen dat de verzoekende partij niet beschikt over een actueel belang. ${ }^{145}$

In voormelde gevallen is er geen mogelijkheid om de schending van het vormvereiste door de burger te herstellen, terwijl de bestuurlijke lus het bestuur wel de mogelijkheid biedt om de schending van bepaalde vormvereisten te zuiveren. In het eerste geval is het ontbreken van de mogelijkheid tot zuivering verdedigbaar, want het gebrek aan ondertekening lijkt niet te kunnen worden gedekt nu zulks onzekerheid met zich kan meebrengen betreffende de verbintenissen van de inschrijvers. Op het moment dat de aanbestedende overheid dan ook een beslissing diende te nemen, was er geen zekerheid over de verbintenis van een van de inschrijvers. Ook in het tweede geval is het gebrek aan de mogelijkheid om het gebrek te regulariseren verdedigbaar. Op het moment dat de gouverneur diende te beslissen over het al dan niet toekennen van een wapenvergunning was er geen zekerheid over het al dan niet voorhanden zijn van een wettige reden, laat staan van welke wettige reden.

In het verslag van de commissie-Berx, dat hiervoor reeds werd aangehaald, wordt gesteld: 'Burgers krijgen terecht steeds vaker de mogelijkheid om een onvolledig dossier te vervolledigen. Zo ook moeten bestuurlijke overheden de kans krijgen om procedure- en vormfouten tijdig te herstellen.' Hoewel in de voormelde voorbeelden de niet-toepassing van de bestuurlijke lus verdedigbaar is, kan toch de vraag worden gesteld of het bestuur geen algemene verplichting heeft om de burgers de mogelijkheid te geven dossiers te vervolledigen om vormfouten recht te zetten, als

I43 Het zuinigheidsbeginsel belet dat de opdracht aan een nog lagere inschrijver wordt toegewezen wanneer die geen regelmatige offerte heeft ingediend ( $\mathrm{RvS}_{3}$ januari 2012, nr. 217.103, nv Lampiris).

I44 RvS I9 augustus 2010, nr. 206.917, Vermetten.

I45 RvS 3 maart 20II, nr. 2II.724, Cox. 
compensatie voor het feit dat het bestuur met de bestuurlijke lus de mogelijkheid krijgt dergelijke fouten te zuiveren.

Zo kunnen wij een situatie schetsen waarbij een burger 'bij zijn aanvraag' bepaalde documenten dient voor te leggen. Stel dat bij de aanvraag de vereiste documenten niet werden voorgelegd, maar dat zij evenwel nog vóór het nemen van de beslissing door het bestuur aan laatstgenoemde werden overgelegd. De Raad van State heeft al geoordeeld dat een zogenoemde 'documentaire ontvankelijkheidsvoorwaarde' wordt gesteld op het ogenblik van het indienen van de aanvraag en dat die ontvankelijkheidsvoorwaarden moeten worden beoordeeld op het ogenblik van het indienen van de aanvraag. ${ }^{16}$ In het arrest nr. 70.769 van 28 november 201 I had de Raad voor Vreemdelingenbetwistingen (die oordeelt over beroepen in het kader van de wet van 15 december 1980 betreffende de toegang tot het grondgebied, het verblijf, de vestiging en de verwijdering van vreemdelingen ${ }^{\mathrm{I} 47}$ nochtans geoordeeld dat geen rekening houden met dergelijk stuk 'kennelijk onredelijk' ${ }^{\mathrm{s} 48}$ is:

'In het licht van het voorgaande laat de Raad gelden dat op het ogenblik van het nemen van de bestreden beslissing was voldaan aan de in artikel gter van de vreemdelingenwet voorziene documentaire ontvankelijkheidsvereiste. Ten tijde van het nemen van de bestreden beslissing lag immers een kopie van eerste verzoeksters Armeens paspoort voor dat, weliswaar op een later tijdstip, bij de aanvraag om machtiging tot verblijf was gevoegd. De verwerende partij had op het ogenblik van het nemen van de bestreden beslissing, i.e. op 23 augustus 2011, derhalve kennis van het identiteitsdocument van eerste verzoekster. De Raad wijst er dienaangaande op dat de regelmatigheid van een administratieve beslissing dient te worden beoordeeld in functie van de gegevens waarover het bestuur op het ogenblik van het nemen van de beslissing kon beschikken om deze te nemen. Aangezien de verwerende partij niet alle elementen die op het moment van het nemen van de bestreden beslissing aanwezig waren in het administratief dossier in overweging heeft genomen, is de Raad bijgevolg van mening dat de verwerende partij niet op kennelijk redelijke wijze tot de conclusie is gekomen dat de aanvraag niet vergezeld ging van een identiteitsdocument of een bewijselement of bewijselementen die samen genomen de constitutieve elementen van identiteit weergeven.

De Raad merkt volledigheidshalve op dat uit de voorbereidende werkzaamheden van de wet van 29 december 2010 houdende diverse bepalingen (Verslag over het wetsontwerp houdende diverse

I46 RvS 6 november 20I2, nr. 221.269, Belgische Staat.

I47 BS 3 I december i980. Deze wet werd meermaals gewijzigd.

I48 De begrippen 'marginale toetsing' en 'kennelijk onredelijk' werden in het arrest nr. 220.242 van ro juli 2012 door de Raad van State als volgt omschreven: 'Er kan slechts sprake zijn van de schending van het redelijkheidsbeginsel wanneer een beslissing, waarvan vastgesteld wordt dat ze op deugdelijke grondslagen berust, inhoudelijk dermate van het normale beslissingspatroon afwijkt dat geen ander naar kennis en kunde redelijk bekwaam en naar feitelijk optreden redelijk handelend bestuur in dezelfde omstandigheden die beslissing zou nemen. Eenmaal evenwel vastgesteld is dat een bestuur die grens heeft overschreden, kan het besluit enkel zijn dat zulk bestuur onredelijk heeft gehandeld. Met andere woorden, begrippen als "marginale toetsing" of "kennelijk onredelijk" mogen als richtsnoer voor de rechter niet zo worden opgevat dat een bestuur best nog "een beetje" onredelijk mag zijn, zonder gevaar tegen een nietigverklaring aan te lopen. Het zijn ook geen sacrale termen die de rechter voor de dag moet halen telkens hij een schending van het beginsel vaststelt.' 
bepalingen, Parl.St. Senaat 2010-11, nr. 5-609/5) kan worden afgeleid dat bij een aanvraag om machtiging tot verblijf op grond van artikel gter van de vreemdelingenwet een identiteitsdocument moet worden voorgelegd, teneinde zekerheid te verkrijgen omtrent de identiteit van de aanvrager. Er wordt evenwel nergens expliciet gesteld dat dit document uitsluitend kan worden voorgelegd op het moment van het indienen van de aanvraag. Noch uit de uitdrukkelijke bewoordingen van artikel gter van de vreemdelingenwet, noch uit de memorie van toelichting bij voornoemde bepaling blijkt dat het uitgesloten zou zijn een ontbrekend document toe te voegen aan een reeds ingediende aanvraag om machtiging tot verblijf voordat het bestuur een beslissing heeft genomen.

Het komt kennelijk onredelijk voor dat er geen rekening werd gehouden met het door eerste verzoekster op 11 augustus 2011 voorgelegde stuk.'

Op het ogenblik van het nemen van de bestreden beslissing is het bestuur in een dergelijk geval op de hoogte van de inhoud van de alsnog overgelegde documenten, waardoor de situatie anders is dan in voormeld beschreven gevallen waarin de aanbestedende overheid op het moment van de bestreden beslissing geen zekerheid had over de verbintenis van een van de inschrijvers of de gouverneur geen zekerheid had over het al dan niet voorhanden zijn van een wettige reden voor het voorhanden hebben van een wapen. Terwijl het voorontwerp voorziet in de mogelijkheid voor het bestuur om zijn vormgebreken te herstellen na het nemen van de bestreden beslissing, kan de burger zijn vormgebreken niet herstellen vóór het nemen van de bestreden beslissing.

Voor een beoordeling van de bestuurlijke lus uit het oogpunt van het gelijkheidsbeginsel is voormeld onderscheid weinig of niet pertinent, omdat de situatie van het bestuur dat optreedt in het algemeen belang objectief verschilt van die van een burger of vereniging die een persoonlijk of alleszins bijzonder belang verdedigt. Toch is het onderscheid, al is het maar omwille van opportuniteitsredenen, voor discussie vatbaar.

Ten slotte kunnen vragen rijzen wat betreft de niet-toepasselijkheid van de bestuurlijke lus in geval van het cassatieberoep. ${ }^{149}$ Wanneer heden de Raad van State een arrest van de Raad voor Vergunningsbetwistingen verbreekt, is het niet uitgesloten dat in de nieuwe procedure voor die Raad de bestuurlijke lus wordt toegepast en het beroep door de Raad voor Vergunningsbetwistingen uiteindelijk wordt verworpen na herstelling van de bestreden beslissing. De rechtszoekende wordt op die manier geplaatst in een voor hem op het eerste gezicht negatievere situatie dan indien er cassatieberoep bij de Raad van State wordt ingesteld tegen het arrest van een rechtscollege dat, na vernietiging door de Raad van State, de toepassing van de bestuurlijke lus niet toelaat (bijvoorbeeld de Raad voor Vreemdelingenbetwistingen of de

I49 Daargelaten de vraag of in een 2Ie-eeuwse rechtspraak nog wel plaats is voor een cassatieprocedure en of het niet beter is dat de beroepsrechter het geschil definitief beslecht. 
Raad voor betwistingen inzake studievoortgangsbeslissingen). ${ }^{150}$ Toch is het weinig waarschijnlijk dat de enkele invoering van de bestuurlijke lus in de rechtspleging voor een bepaald administratief rechtscollege tot een veralgemeende toepassing ervan in procedures voor andere zulke rechtscolleges zou verplichten. Immers, vaste rechtspraak van het Grondwettelijk Hof luidt als volgt:

'Het verschil in behandeling tussen bepaalde categorieën van personen dat voortvloeit uit de toepassing van verschillende procedureregels in verschillende omstandigheden, houdt op zich geen discriminatie in. Van discriminatie zou slechts sprake zijn indien het verschil in behandeling dat voortvloeit uit de toepassing van die procedureregels, een onevenredige beperking van de rechten van de daarbij betrokken personen met zich zou meebrengen. ${ }^{151}$

\section{Artikel 6 lid I EVRM}

De vergelijking kan niet worden gemaakt met het geval waarin een auditeur of staatsraad zich moet uitspreken in het vernietigingscontentieux over een geval waarin hij voorheen optrad in het kader van de Afdeling Wetgeving. Het is niet zo dat bij de toepassing van de bestuurlijke lus het gevaar bestaat dat de Raad van State zich zou gebonden voelen aan een standpunt dat hij voorheen heeft ingenomen, omdat er gewoonweg geen vroeger standpunt bestaat. ${ }^{152}$ Gedurende de uitoefening van de rechterlijke functies stelt de Raad van State vast dat er een schending van een vormvereiste is, maar dat niet wordt overgegaan tot vernietiging indien die wordt hersteld. Maar in die functie wordt wel eerst standpunt bepaald over het bestaan van een gebrek in het bestreden besluit en de herstelbaarheid van dat gebrek, en (pas) dan over het al dan niet effectieve herstel van het gebrek en eventueel over een daartoe genomen bijkomend besluit.

Artikel 6 lid I EVRM luidt als volgt:

'Bij het vaststellen van zijn burgerlijke rechten en verplichtingen of bij het bepalen van de gegrondheid van een tegen hem ingestelde vervolging heeft een ieder recht op een eerlijke en openbare behandeling van zijn zaak, binnen een redelijke termijn, door een onafhankelijk en onpartijdig gerecht dat bij de wet is ingesteld. (...)'.

I50 Iedere student ingeschreven aan een universiteit, hogeschool of andere ambtshalve geregistreerde instelling van de Vlaamse Gemeenschap kan een verzoekschrift indienen bij de Raad voor betwistingen inzake studievoortgangsbeslissingen wanneer hij een studievoortgangsbeslissing wil betwisten.

I5I Bv. GwH 30 mei 2013, nr. 76/2013.

I52 Zie EHRM 28 september I995, nr. I4570/89 (Procola t. Luxemburg), alsook EHRM 6 mei 2003, nr. 39343/98 (Kleyn e.a. t. Nederland), waarin als volgt werd geoordeeld: 'Nevertheless, as illustrated in Procola(cited above), the consecutive exercise of advisory and judicial functions within one body may, in certain circumstances, raise an issue under Article 6 S I of the Convention as regards the impartiality of the body seen from the objective viewpoint. In this context the Court reiterates that it is crucial for tribunals to inspire trust and confidence.' 
Een geschil tussen een rechtsonderhorige en de Staat kan vallen binnen het toepassingsgebied van artikel 6 lid I EVRM. ${ }^{153}$ Tevens heeft de Raad van State beslist dat artikel 6 lid I EVRM niet belet dat een geschil over burgerlijke rechten en verplichtingen wordt beslecht door een bestuurlijke overheid die niet voldoet aan de waarborgen van die bepaling, voor zover die beslissing vatbaar is voor een beroep bij een rechterlijke instantie die over een voldoende rechtsmacht beschikt en beantwoordt aan de waarborgen van artikel 6 lid I EVRM.

Het Grondwettelijk Hof heeft in het arrest van 30 maart 201 m met nr. 44/20II geoordeeld als volgt:

'B.6. (...) Het Hof dient bijgevolg, bij de toetsing aan de artikelen 10 en 11 van de Grondwet, rekening te houden met de waarborgen vervat in dat artikel 6 en, met name, de waarborg dat een onafhankelijke en onpartijdige rechter een controle met volle rechtsmacht kan uitoefenen op de door de bevoegde administratieve overheid opgelegde geldboete.

(...)

B.10.1. Uit de rechtspraak van de Raad van State blijkt dat die een volwaardige jurisdictionele toetsing uitoefent, zowel aan de wet als aan de algemene rechtsbeginselen. De Raad van State gaat daarbij na of de aan zijn toezicht voorgelegde overheidsbeslissing de vereiste feitelijke grondslag heeft, of die beslissing uitgaat van correcte juridische kwalificaties en of de opgelegde straf niet kennelijk onevenredig is met de vastgestelde feiten. Wanneer hij die beslissing vernietigt, dient de overheid zich te schikken naar het arrest van de Raad van State: indien de overheid een nieuwe beslissing neemt, mag zij de motieven van het arrest dat de eerste beslissing heeft vernietigd, niet negeren; indien zij in de vernietiging berust, wordt de betrokkene geacht niet gestraft te zijn geweest.

B.10.2. Bovendien kan de Raad van State, in de omstandigheden bedoeld in artikel 17 van de gecoordineerde wetten op de Raad van State, gelasten dat de uitvoering van de beslissing om sancties op te leggen wordt geschorst, in voorkomend geval door uitspraak te doen bij uiterst dringende noodzakelijkheid.

B.10.3. De rechtzoekenden beschikken derhalve over een daadwerkelijke jurisdictionele waarborg, voor een onafhankelijk en onpartijdig rechtscollege, tegen de administratieve sanctie die hun kan worden opgelegd.'

In verband met beslissingen van administratieve overheden heeft de Raad van State sinds het arrest van 20 december 1984 met nr. 24.937 steeds aangenomen dat hij een rechtscollege met volle rechtsmacht is, aangezien zijn annulatiebevoegdheid slaat op alle aspecten van de wettigheid zowel in rechte als in feite, met inbegrip van de evenredigheid. Volgens vaste rechtspraak is de Raad van State dan ook een rechtscollege dat enerzijds beantwoordt aan de vereisten van artikel 6.I EVRM en dat anderzijds 'volle rechtsmacht' heeft. ${ }^{154}$

I53 EHRM 28 juni I978, nr. 6232/73 (König t. Duitsland).

I54 Zie bijvoorbeeld RvS ig september 20II, nr. 215.I99, Van Lancker en RvS 6 december 20I2, nr. 221.638, Nijskens. 
De vraag dient te worden gesteld of de Raad van State, als eenmaal zijn bevoegdheden zijn uitgebreid, nog steeds zal beantwoorden aan de vereisten van artikel 6 lid I EVRM. Hierbij is het gepast te verwijzen naar de uitspraak $11 / 915 \mathrm{WWB}^{155}$ van I6 april 2013 van de Nederlandse Centrale Raad van Beroep. De feiten van die zaak kunnen als volgt worden samengevat.

M. ontving van 28 oktober 2003 tot I juni 2008 bijstand als alleenstaande. In diens woning (het uitkeringsadres) wordt echter op ro mei 2008 door de politie een hennepplantage aangetroffen. Naar aanleiding daarvan wordt een onderzoek ingesteld naar de woonsituatie van M. Er wordt uiteindelijk door het college van burgemeester en wethouders van Nijmegen op 25 mei 2009 besloten dat M. en appellante een gezamenlijke huishouding voeren en dat $M$. daarvan geen melding heeft gemaakt bij het college. De kosten van de sinds 16 oktober 2007 aan M. verleende bijstand worden dan ook tot een bedrag van 8.I68,95 euro mede van appellante teruggevorderd. Tegen dat besluit wordt beroep ingesteld bij de rechtbank te Arnhem die het college uiteindelijk verzoekt zijn standpunt nader te onderbouwen, want het bestreden besluit was onvoldoende gemotiveerd. In de brief van de rechtbank aan het college wordt het volgende gesteld:

'Over de periode vanaf 16 oktober 2007 tot en met 23 oktober 2008 (...) stelt verweerder zich op het standpunt dat eiseres met de heer [M.] aan de [adres 1] te [plaatsnaam] een gezamenlijke huishouding voerde. De rechtbank verzoekt verweerder hierbij (...) dit standpunt nader te onderbouwen. Daartoe acht de rechtbank nadere - door de sociale recherche opgenomen en in ambtsedig opgemaakte processen-verbaal neergelegde - verklaringen van de buurtbewoners [getuige 1], [getuige 3] en [getuige 2] noodzakelijk. Uit die verklaringen zal moeten blijken hoe lang zij aan de [adres 1] woonachtig zijn, wat hun relatie tot eiseres en de heer [M.] was/is en op grond van welke door hen geconstateerde feiten of omstandigheden (bijvoorbeeld hoe vaak zagen zij de heer [M.] in de woning en/of waren er vaste momenten waarop zij constateerden dat [M.] in de woning aanwezig was) zij tot de conclusie zijn gekomen dat de heer [M.] tegelijkertijd met eiseres en haar zoon op de [adres 1] is komen wonen en hij over de gehele periode in geding woonachtig was op de [adres 1].'

De vervolgens door het college overgelegde aanvullende verklaringen van de buurtbewoners worden door de rechtbank als voldoende feitelijke grondslag beschouwd voor het standpunt van het college dat $M$. in de periode van I6 oktober 2007 tot I juni 2008 zijn hoofdverblijf heeft gehad op het adres van appellante. Terecht had het college dus geoordeeld dat er sprake was van een gezamenlijke huishouding. Het beroep tegen het bestreden besluit werd door de rechtbank gegrond verklaard, het bestreden besluit werd vernietigd maar de rechtsgevolgen ervan werden geheel in stand gehouden.

Tegen de uitspraak van de rechtbank te Arnhem wordt hoger beroep ingesteld bij de Centrale Raad van Beroep, waar appellante aanvoert dat de rechtbank haar 
beslissing niet op de aanvullende verklaringen van de buurtbewoners had mogen baseren. De rechtbank had namelijk erg specifiek aangegeven op welke wijze het college zijn standpunt nader diende te onderbouwen om daarmee alsnog een gezamenlijke huishouding te kunnen aannemen. Volgens appellante verdroeg dit zich niet met het beginsel van wapengelijkheid en de overige eisen die artikel 6 EVRM stelt.

De Centrale Raad van Beroep oordeelt dat aan een besluit dat op onvoldoende feitelijke grondslag berust een gebrek kleeft en '[v]an een dergelijk gebrek kan niet worden gezegd dat per definitie de mogelijkheid van herstel via een informele bestuurlijke lus is uitgesloten' (r.o. 4.4). Toch beslist hij dat de uitspraak van de rechtbank, voor zover daarbij de rechtsgevolgen van het vernietigde besluit in stand zijn gelaten, moet worden vernietigd. De Centrale Raad van Beroep motiveert als volgt:

4.5. Het onder 2.1 weergegeven verzoek van de rechtbank aan het college om zijn standpunt inzake de gezamenlijke huishouding van appellante en [M.] nader te onderbouwen is zeer gedetailleerd. De rechtbank achtte het noodzakelijk dat de buurtbewoners door de sociale recherche opnieuw zouden worden gehoord en dat hun verklaringen in ambtsedig opgemaakte processen-verbaal zouden worden neergelegd. Voorts heeft de rechtbank nauwkeurig aangegeven op welke punten de sociale recherche de buurtbewoners zou moeten bevragen. Door haar verzoek zo minutieus te formuleren, heeft de rechtbank de schijn gewekt zich te verbinden met het mogelijke resultaat van het door het college op haar verzoek verrichte onderzoek. Bij appellante kon daardoor de indruk ontstaan dat de rechtbank haar onbevangenheid had verloren bij de beoordeling van de mogelijke verweren en bewijzen van appellante. De wijze waarop de rechtbank in het geval van appellante gestalte heeft gegeven aan de informele bestuurlijke lus, verdraagt zich daarom niet met de eisen die artikel 6 van het EVRM stelt. De beroepsgrond van appellante dat de rechtbank ten onrechte haar beslissing op de aanvullende verklaringen van de buurtbewoners heeft gebaseerd treft dan ook doel.'

De Raad van State zal er dan ook moeten over waken dat bij het gebruik van de bestuurlijke lus artikel 6 lid I EVRM wordt geëerbiedigd bij het formuleren van de instructie hoe de tekortkoming kan worden rechtgezet. Hij zal erover moeten waken niet op de stoel van het bestuursorgaan te gaan zitten. ${ }^{156}$ Ook hier lijkt te moeten worden vastgesteld dat het aanwenden van de (informele) bestuurlijke lus door het auditoraat er niet toe zou leiden dat moet worden gevreesd dat de bevoegde kamer, die volledig los staat van het auditoraat, niet langer zou kunnen oordelen overeenkomstig de vereisten van artikel 6 lid I EVRM.

\section{Besluit}

In april 2013 werd een voorontwerp houdende hervorming van de bevoegdheid, de procedureregeling en de organisatie van de Raad van State door de Ministerraad

I56 H. Bortels, De bestuurlijke lus: aanzet naar een meer oplossingsgerichte bestuursrechter?', TBP 2013/5, (302), 306 . 
goedgekeurd, waarin is voorzien dat de schending van een vormvereiste kan worden opgelost door gebruik te maken van de bestuurlijke lus in plaats van te vernietigen. In 2012 werd de bestuurlijke lus reeds opgenomen in de procedure voor de Raad voor Vergunningsbetwistingen, maar tot op heden heeft die Raad nog geen arresten gewezen waarin toepassing werd gemaakt van de bestuurlijke lus. Ondertussen is wel een beroep tot vernietiging van die bepalingen van het decreet van 6 juli 20I2, die de bestuurlijke lus in de procedure voor de Raad voor Vergunningsbetwistingen invoeren, ingesteld bij het Grondwettelijk Hof, waarin onder andere de schending van het Verdrag van Aarhus, van Richtlijn 2011/92/EU van het Europees Parlement en de Raad van 13 december 20 I betreffende de milieueffectbeoordeling van bepaalde openbare en particuliere projecten, van de beginselen van het recht van verdediging, tegenspraak, onafhankelijkheid en onpartijdigheid van de rechter, de wapengelijkheid en de formele motiveringsplicht wordt ingeroepen.

Het voorontwerp bepaalt de voorwaarden om de bestuurlijke lus te gebruiken, waarbij opvalt dat het vereiste, dat belanghebbenden die niet als partij aan het geding deelnemen niet onevenredig mogen worden benadeeld door het gebruik van de bestuurlijke lus, niet wordt opgenomen, hoewel dit wel het geval is voor de procedure voor de Raad voor Vergunningsbetwistingen en de Nederlandse bestuursrechter. Ook kan de Belgische Raad van State, in tegenstelling tot de Nederlandse Raad van State, de bestuurlijke lus niet opleggen aan het bestuur.

Er zullen zich twee mogelijkheden voordoen: (I) het auditoraat besluit dat de zaak zich leent voor de toepassing van de bestuurlijke lus, of (2) pas bij tussenarrest wordt beslist dat de zaak zich leent voor de toepassing van de bestuurlijke lus. In beide gevallen zal het auditoraat wel eerst alle middelen moeten hebben onderzocht. Ook zal na de uitvoering van het tussenarrest nog een onderzoek plaatsvinden of het gebrek volledig is hersteld en niet is aangetast door nieuwe gebreken. Is het gebrek volledig hersteld, dan wordt het beroep verworpen (een toepassing van artikel I4ter RvS-wet is niet mogelijk, terwijl in Nederland in een dergelijk geval de gevolgen van het vernietigde besluit wel in stand kunnen worden gehouden). Als, in het kader van de toepassing van de bestuurlijke lus, een beslissing met een andere inhoud wordt genomen, dan kan die worden aangevochten met een apart annulatieberoep. Tevens moet rekening worden gehouden met artikel 9 van het Verdrag van Aarhus bij het nemen van een nieuwe beslissing met een milieurechtelijke impact, want 'enig' besluit, handelen of nalaten kan volgens dat Verdrag worden aangevochten.

In de rechtsleer wordt kritiek geuit op de bestuurlijke lus en een bijkomend punt van kritiek is dat in België een auditoraat in de Raad van State bestaat. Wanneer in het auditoraatsverslag wordt vastgesteld dat het bestuur een vormvereiste heeft geschonden, waarbij wordt voorgesteld om de bestreden beslissing te vernietigen, heeft het bestuur de mogelijkheid om ervoor te opteren geen voortzetting van de procedure van de rechtspleging te verzoeken, waarna de bestreden beslissing bij verkorte procedure wordt vernietigd, of om de bestreden beslissing in te trekken. Ongeacht of al dan niet de toepassing van de bestuurlijke lus wordt voorgesteld, moet het bestuur de mogelijkheid blijven aanwenden om geen voortzetting van de 
procedure van de rechtspleging te vragen, waarna de Raad van State zonder enige verdere formaliteiten de bestreden beslissing kan vernietigen en het bestuur een nieuwe beslissing kan nemen, of om de bestreden beslissing in te trekken. Zo gebeurt het nu al geregeld dat het bestuur, na vaststelling in het auditoraatsverslag dat er een schending van bijvoorbeeld de motiveringsverplichting is waardoor wordt voorgesteld de bestreden beslissing te vernietigen, geen voorzetting vraagt en, in afwachting van het vernietigingsarrest, de fouten die werden vastgesteld door de auditeur herstelt in de nieuwe beslissing. Enige tijd na het vernietigingsarrest wordt de nieuwe beslissing dan genomen. Renders en Gors stellen dan ook terecht dat de intrekking de voorkeur moet krijgen op de toepassing van de bestuurlijke lus. ${ }^{157}$ Daarenboven kan de vraag worden gesteld of de rechter niet gewoon anders moet omgaan met de schending van een vormvereiste (bijvoorbeeld meer belangenafweging in een schorsingsprocedure), waarbij onder meer kan worden verwezen naar het arrest Danthony van de Franse Raad van State en het relativiteitsvereiste zoals dit reeds in de Nederlandse wetgeving is opgenomen. Ook de Nederlandse praktijk van de informele lus zou perfect kunnen worden aangewend door het auditoraat om zo vroeg mogelijk in de procedure te kunnen wijzen op een gebrek in de bestreden beslissing.

Sommige auteurs argumenteren dat het gebruik van de bestuurlijke lus door de Nederlandse Raad van State afhangt van het toeval. Er zijn gevallen waarin de bestuurlijke lus niet mogelijk lijkt, zoals in het geval van cassatieberoep, kort geding (hoewel een aparte procedure zal worden voorzien om het kort geding om te zetten in een beroep ten gronde om zo de bestuurlijke lus te kunnen toepassen), schadeloosstellingen, maar ook in het kader van procedures op grond van een bijzondere wet (zoals bij de benoeming van de burgemeesters van de randgemeenten) en wanneer de Raad van State beschikt over een hervormingsbevoegdheid. In andere gevallen kan de bestuurlijke lus worden toegepast, maar kunnen er toch belemmeringen zijn. Wanneer een adviesverplichting over het hoofd werd gezien, kan de bestuurlijke lus worden gebruikt, maar de Raad van State moet er in wezen van overtuigd zijn dat het advies de inhoud van de bestreden beslissing niet meer zal beïnvloeden.

De bestuurlijke lus is ingesteld enkel ten bate van het bestuur, maar toch kan de vraag worden gesteld - zeker in het licht van het arrest nr. 70.769 van 28 november 20II van de Raad voor Vreemdelingenbetwistingen - of het bestuur geen verplichting heeft om tevens de burgers de mogelijkheid te geven dossiers te vervolledigen om vormfouten recht te zetten. De burger mag daarenboven niet twijfelen aan de 'onbevangenheid' van de Raad van State wanneer die de bestuurlijke lus aanwendt.

Het is ten slotte vreemd te noemen dat het bestuur de schending van een vormvereiste niet zou verkiezen op te lossen met de verkorte procedure die kan worden ingesteld indien in het auditoraatsverslag de vernietiging wordt voorgesteld of met

I57 Zie 'Intervention de David Renders et de Benoit Gors', Publicum juni 20I3, 30. 
intrekking, maar wel door de toch wel omslachtige procedure van de bestuurlijke lus te gebruiken, waarin de Raad van State opnieuw dient te oordelen over de herstelbeslissing en waarin nieuwe middelen kunnen worden opgeworpen die, met inachtneming van het recht van verdediging, eventueel aan de partijen moeten worden voorgelegd voor repliek, waarna dan het auditoraat eventueel een aanvullend verslag dient op te stellen. Er mag ook niet uit het oog worden verloren dat iedere vernietiging, waarna een nieuwe beoordeling dient te volgen, kan leiden tot een andere kijk op een dossier waardoor de vernietiging op grond van een vormgebrek niet steeds kan worden gereduceerd tot een pyrrusoverwinning. Een vernietiging op louter vormelijke redenen kan namelijk het begin zijn van een serie procedures die uiteindelijk kunnen leiden tot een waarlijk overwinning voor de rechtszoekende.

\section{Naschrift: Overzicht van de verschillende toepassingen van de bestuurlijke lus door de Raad van State}

a. Het auditoraat oordeelt dat een middel zich leent voor het gebruik van de bestuurlijke lus

Het auditoraat moet eerst alle middelen onderzoeken. De partijen kunnen dan in de laatste memories al hun opmerkingen over de toepassing van de bestuurlijke lus laten gelden.

De Raad van State spreekt zich uit over de gegrondheid van het middel en over de eventuele toepassing van de bestuurlijke lus.

De mogelijkheden zijn dan de volgende:

I. De Raad vindt het middel gegrond, maar vindt dat het niet in aanmerking komt voor de bestuurlijke lus. De bestreden beslissing wordt vernietigd op grond van het middel.

2. De Raad vindt het middel gegrond en vindt, samen met het auditoraat, dat het in aanmerking komt voor de bestuurlijke lus. Bij tussenarrest wordt vastgesteld welke de herstellende handeling is die moet worden aangenomen en binnen welke termijn.

3. De Raad vindt het middel ongegrond. De zaak wordt ten gronde opgelost op basis van het onderzoek van al de middelen die door het auditoraat werden onderzocht.

b. Het auditoraat oordeelt dat er geen enkel middel gegrond is en besluit tot de verwerping

De mogelijkheden zijn dan de volgende:

I. De Raad treedt het oordeel van het auditoraat bij, verklaart dan ook alle middelen ongegrond en verwerpt het beroep.

2. De Raad vindt een van de middelen gegrond, maar vindt niet dat er toepassing moet worden gemaakt van de bestuurlijke lus. De Raad moet vernietigen op grond van dat middel.

3. De Raad vindt een van de middelen gegrond, maar vindt dat de bestuurlijke lus kan worden toegepast. In het tussenarrest moet worden vastgesteld welke de herstellende handeling is die moet worden gesteld en binnen welke termijn. 
c. Het auditoraat oordeelt dat een middel gegrond is en besluit tot de vernietiging op grond van dat enige onderzochte middel en stelt dat geen toepassing kan worden gemaakt van de bestuurlijke lus

In deze hypothese is er, overeenkomstig artikel 24 lid 2 RvS-wet, maar één middel onderzocht.

De mogelijkheden zijn dan de volgende:

I. De Raad treedt het oordeel van het auditoraat bij. De bestreden beslissing wordt vernietigd op grond van het middel.

2. De Raad treedt het oordeel van het auditoraat niet bij en bevindt het middel niet gegrond. Het middel wordt dan ook verworpen en het auditoraat wordt belast met een verdere onderzoeksmaatregel (onderzoek van de andere middelen).

3. De Raad treedt het oordeel van het auditoraat, dat het middel gegrond is, bij, maar meent dat het in aanmerking komt voor de toepassing van de bestuurlijke lus. In een dergelijk geval is de toepassing van de bestuurlijke lus enkel mogelijk indien de Raad zelf alle andere middelen onderzoekt. Hoewel op gespannen voet met artikel $24 \mathrm{RvS}$-wet zal het auditoraat worden belast met een verdere onderzoeksmaatregel (onderzoek van de andere middelen). 